\title{
„Barwy Białe” w drodze na pomoc walczącej Warszawie. Zbrodnie AK na Żydach
}

„Po otrzymaniu tego rozkazu od «Zawiszy» ja i Stec Jan ${ }^{1}$ zebraliśmy swoje plutony, w których było około 60 członków AK, i udaliśmy się na miejsce w lasy siekierzyńskie pow. Kielce, gdzie zaprowadził nas jeden z żydków przebywających na kwaterze «Zawiszy». Tu na miejscu zobaczyliśmy w szałasach leśnych około 30-tu osób narodowości żydowskiej, w tym i kilka kobiet. Ja wtedy wydałem rozkaz, aby ich wszystkich zebrać i wyprowadzić na polanę leśną. Następnie po wyprowadzeniu ich na polanę leśną wydałem rozkaz podoficerowi broni sierżantowi ps. «Bolrok» $»^{2}$, aby wykonał wyrok śmierci na tych osobach narodowości żydowskiej, a sam odszedłem kilkanaście metrów w las, nie chcąc patrzeć na wykonanie tego wyroku. Po oddaniu strzałów do tych osób przez pozostałych członków AK ja wróciłem z powrotem $z$ lasu na tą polanę i widziałem leżących zabitych już Żydów, a do niektórych jeszcze żyjących żołnierze oddali jeszcze kilka strzałów. Tu na tej polanie mieliśmy ich pochować, lecz w tym czasie przyszedł goniec od «Zawiszy», aby natychmiast wracać do oddziału, co też uczyniliśmy, natomiast pomordowane osoby narodowości żydowskiej pozostawiliśmy nie zakopane na polanie leśnej w lasach k. Siekierna pow. Kielce"3.

Tak opisał przebieg wydarzeń Edward Sternik „Grzegorz”, przesłuchiwany przez oficera śledczego Wojewódzkiego Urzędu Bezpieczeństwa Publicznego (WUBP) w Kielcach. Dotyczą one egzekucji, jaką 17 sierpnia 1944 r. $^{4}$ - na rozkaz por. Kazimierza Olchowika „Zawiszy” - wykonał oddział „Barwy Białe” na bezbronnych Żydach. Oddział ów (jako 5. kompania 2. Pułku Piechoty Legionów AK) wchodził w skład 2. Dywizji Piechoty Armii Krajowej, dowodzonej przez płk. Antoniego

\footnotetext{
${ }^{1}$ Zob. noty biograficzne w układzie alfabetycznym na końcu tekstu.

${ }^{2}$ W dokumentach pojawiają się też zapisy „Bojlrok”, „Bojrok” i „Bolerok”.

${ }^{3}$ Archiwum Instytutu Pamięci Narodowej Oddział w Kielcach (dalej AIPN Ki), 013/25, t. 2, Protokół przesłuchania podejrzanego z 31 III 1949 r., k. 137-138. We wszystkich cytowanych dokumentach zachowano oryginalną pisownię.

${ }^{4}$ Jest to najbardziej prawdopodobna data dzienna ustalona na podstawie kalendarium przemieszczania się 2. pp Leg. AK, który przebywał w Siekiernie w dniach 16 i 17 VIII 1944 r., po czym wyruszył w dalszą drogę w nocy z 17 na 18 sierpnia. Zob. Piotr Sierant, 2 Pułk Piechoty Legionów Armii Krajowej, Warszawa: Volumen-Bellona, 1996, s. 114.
} 
Żółkiewskiego „Lina”. Dywizji, która, wykonując rozkaz komendanta głównego AK gen. Bora-Komorowskiego, zmierzała na pomoc walczącej Warszawie.

Oddział „Barwy Białe” był jednym z tych oddziałów partyzanckich na Kielecczyźnie, które już w okresie swego istnienia budziły ogromne kontrowersje. Władysław Zwiejski „Jaruga”, komendant okręgu opatowskiego Batalionów Chłopskich, pisał o nim 5 marca 1944 r.: „[...] nazwa oddziału nie jest przypadkowa, lecz ma swoją wymowę polityczną i pachnie po prostu prowokacją - a z punktu widzenia wojskowego szkodliwą, bo zmusza zarówno członków oddziału, jak i szerokie masy społ[eczeństwa] zorganizowanego i niezorganizowanego - do myślenia o nim jako o grupie politycznej" 5 .

Oddział został powołany za zgodą Komendy Głównej AK w listopadzie 1943 r. $^{6}$ Był on oddziałem dyspozycyjnym podległym bezpośrednio komendantowi Obwodu Opatów - Witoldowi Sągajlle „Sulimie”. Pierwszym dowódcą oddziału był ppor. Konrad Suwalski „Mruk”, wcześniej członek Narodowej Organizacji Wojskowej ${ }^{7}$. W skład oddziału weszli ludzie pochodzący z Ćmielowa i najbliższych okolic. Na początku 1944 r. o Suwalskim zrobiło się głośno, kiedy to nawiązał kontakty z żandarmerią niemiecką z Opatowa ${ }^{8}$. Rozmowy, między innymi w majątku Karola

${ }^{5}$ Archiwum Zakładu Historii Ruchu Ludowego (dalej AZHRL), MiD III/18 „A”, Sprawozdanie Jarugi do Komendy Okręgu III BCh, 5 III 1944 r., k. 3.

${ }^{6}$ Witold Sagajllo, The Man in the Middle. A Story of the Polish Resistance 1940-1945, London: L. Cooper-Secker \& Warburg, 1984, s. 121; Antoni Sułowski, U podnóża Gór Świętokrzyskich. Z dziejów obwodu Opatów ZWZ-AK 1939-1945, Warszawa: PAX, 1987, s. 116; Wojciech Borzobohaty, „Jodła” Okręg Radomsko-Kielecki ZWZ-AK 1939-1945, wyd. 2, Warszawa: PAX, 1988, s. 45.

${ }^{7}$ Narodowa Organizacja Wojskowa (NOW), utworzona w październiku 1939 r. przez Stronnictwo Narodowe (SN). W listopadzie 1942 r. NOW została włączona w struktury Armii Krajowej. Działacze Stronnictwa i członkowie NOW, którzy nie uznali decyzji o scaleniu, w styczniu 1943 r. powołali nowy Zarząd Główny SN, a w porozumieniu ze Związkiem Jaszczurczym oddziały wojskowe pod nazwą Narodowe Siły Zbrojne (NSZ).

${ }^{8}$ AZHRL, MiD III 18, Przejawy współpracy z Niemcami, b.d., k. 4. Sprawa stała się na tyle głośna, że komendant Obwodu Opatów AK zamieścił komunikat w lokalnym wydaniu „Biuletynu Informacyjnego” (nr 19 z 17 II 1944 r.), w którym czytamy: „Wyjaśnienie. W ostatnich dniach rozeszła się plotka, jakoby polskie organizacje nawiązały kontakt, a nawet przyjazne stosunki z Niemcami. Stwierdzamy, że nie odpowiada to prawdzie. Nie może być mowy o przyjaźni z odwiecznym wrogiem, który nie omijał nigdy i dziś nie pomija żadnej okazji, aby niszczyć wszystko, co tchnie polskością. Źródeł tej plotki należy szukać u samych Niemców. Rozpuszczana jest celem skłócenia wyraźnej i jednolitej postawy całego Narodu Polskiego. Dementujemy więc te niecne insynuacje i uświadamiamy mniej zorientowanych, że naszym obowiązkiem jest w dalszym ciągu utrzymywanie własnej równowagi i zachowanie godności narodowej. Jakiekolwiek wahania w kierunku zaborcy od zachodu czy wschodu byłyby niezgodne z tradycją i dotychczasową nieustępliwą naszą postawą, a w konsekwencji okazałyby się zawsze zgubne”. Władysław Zwiejski „Jaruga” opatrzył ten komunikat następującym komentarzem: „Charakterystyczne momenty: przenoszenie zarzutu na «polskie 
T. Wickenhagena w Sobótce, miały być poświęcone współpracy przy zwalczaniu partyzantki komunistycznej ${ }^{9}$.

Kilkanaście dni później, 12 lutego 1944 r., Suwalski przeprowadził samowolną akcję przeciwko oddziałowi Armii Ludowej im. Bartosza Głowackiego w Wólce Bodzechowskiej ${ }^{10}$. Część zakładników wziętych podczas tej akcji do niewoli, głównie Rosjan, została następnie na rozkaz por. „Nurta” rozstrzelana w Truskolasach przez pluton chorążego Tomasza Wagi „Szorta”11. W konsekwencji doszło do obustronnych krwawych represji, które nie ustały mimo podpisania 25 lutego „rozejmu” pomiędzy AK a AL ${ }^{12}$. Postępowanie Suwalskiego wywołało powszechne oburzenie w powiecie opatowskim, dlatego też, mimo początkowych oporów komendanta obwodu AK, „Mruk” został usunięty ze stanowiska dowódcy oddziału13.

16 lutego 1944 r. dowództwo oddziału „Barwy Białe” objął Władysław Pietrzykowski „Topór”, wcześniej szef Referatu II AK (wywiadu) w Obwodzie Opatów. Jego aktywność, w odróżnieniu od Suwalskiego, została tym razem skierowana przeciwko Batalionom Chłopskim. „Z dniem 1 marca 1944 r. rozpoczęło się - pisał w sprawozdaniu z 5 marca 1944 r. Zwiejski - nowe i, sądzę, ostatnie stadium w rozwoju stosunków między ZWZ a nami. Po rozproszeniu mniejszych grup PPR przystapiono z dniem tym do «pacyfikacji» BCh. Obwodowa grupa lotna AK, obecnie pod dowództwem Topora (osławionego Drewicza - Mrukowi dla oka odebrano dowództwo za rozmowy i kontakty z Niemcami), została skierowana do rejonu południowego z wyraźnym poleceniem spacyfikowania już nie pojedynczych ludzi z BCh, ale całych komórek i oddziałów”"14.

organy». Zaprzeczenie «przyjaźni» - pominięcie milczeniem kontaktów. W zestawieniu z rzeczywistością wyjaśnienie to jest cynicznym kłamstwem” (AHRL, MiD III/18 „A”, Uzupełnienie, b.d., b.p.).

${ }^{9}$ Mieczysław Młudzik, Polem, lasem. Wspomnienia dowódcy oddziału partyzanckiego BCh-LSB, wyd. 3, Warszawa: Ludowa Spółdzielnia Wydawnicza, 1984, s. 117-122; Leszek Popiel, Batalion partyzancki 2 putku piechoty Leg. „Nurt”, „Wojskowy Przegląd Historyczny” 1989, nr 1, s. 186.

${ }^{10}$ Borzobohaty, „Jodła”..., s. 196.

${ }^{11}$ Popiel, Batalion partyzancki..., s. 185; zob. także: Archiwum Instytutu Pamięci Narodowej w Warszawie (dalej AIPN), GK, 411/216, Protokół przesłuchania podejrzanego Władysława Kolasy z 10 II 1949 r., k. 101.

${ }^{12}$ Bogdan Hillebrandt, Partyzantka na Kielecczyźnie 1939-1945, Warszawa: Wydawnictwo MON, 1967, s. 250; Popiel, Batalion partyzancki..., s. 186.

${ }^{13}$ Suwalski, podobnie jak jego zastępca ppor. Aleksander Zalewski „Lisek”, zostali zdegradowani do stopnia strzelca i wcieleni do oddziału „Nurta”. Sprawa „Mruka” pociągnęła za sobą także usunięcie z funkcji komendanta Obwodu Opatów „Sulimy” (Popiel, Batalion partyzancki..., s. 186).

${ }^{14}$ AZHRL, MiD III/18, Sprawozdanie Jarugi do Komendy Okręgu III BCh, 5 III 1944 r., k. 1. Krytycznie do „Barw Białych”, podobnie jak do całego ZWZ-AK w Obwodzie Opatów, odnosił się Zwiejski także po drugiej wojnie światowej. Zob. Władysław Zwiejski, Walczyli w Chłopskich Batalionach. Z dziejów podziemnego ruchu ludowego w obwodzie opatowskim (1939-1944), Warszawa: Ludowa Spółdzielnia Wydawnicza, 1964, s. 243-257. 
17 lutego 1944 r. do oddziału „Barwy Białe”, stacjonującego w Kaliszanach (majątku należącym do Michała Leszczyńskiego „Habdanka”), dołączyli członkowie tzw. sekcji specjalnej Referatu II AK z Podobwodu „300” (Ćmielów): Władysław Kolasa „Leń”, Władysław Cybula „Grzmot”, Ryszard Nowacki „Pobożny”15. Przed wstąpieniem do oddziału (w kwietniu 1943 r.) wspólnie ze Stanisławem Mroczkiem „Jastrzębiem” i Stanisławem Tworkiem „Drozdem” w mieszkaniu Marii Czuby w Goździelinie gm. Bodzechów wymordowali 7 Żydów, w tym 2 kobiety i 2 dzieci (w wieku 6 i 12 lat) ${ }^{16}$. Dom Czubiny spalono. Na procesie Stanisława Różalskiego w 1959 r. Czubina zeznała, że przyszły do niej dwie Żydówki, które mówiły, że są z Bodzechowa i nazywają się Rochamulówny, później akowcy przyprowadzili Frajdę z Goździelina17. Zeznała ponadto, że ludzie mówili, iż pomordowani byli Żydami z Goździelina, Denkówka, Bodzechowa i Zygmuntówki18. Akcją dowodził Stanisław Różalski „Grażyna”, podwładny Józefa Radomskiego „Robaka”, kierownika wywiadu AK na gminę Ćmielów.

Jeden z uczestników mordu, Stanisław Tworek „Jaszczurka”, podczas śledztwa i procesu zeznawał, że rozkaz w sprawie akcji wydał kierownik Referatu II AK w Podobwodzie „300” (Ćmielów) Jan Szpinek „Motyl”. Osobą, która mogłaby potwierdzić ten fakt, był drugi uczestnik mordu - Stanisław Mroczek „Jastrząb”. Ponieważ zmarł on w 1946 r., Szpinek do przypisywanego mu rozkazu nigdy się nie przyznał. Podczas przesłuchań wielokrotnie podkreślał, że mord w Goździelinie był konsekwencją zarządzenia dowództwa obwodu opatowskiego, które miało wydać rozkaz „do wszystkich członków placówek, by patrolowali swoje tereny i likwidowali ukrywających się Żydów, którzy rzekomo mieli dokonywać kradzieży”"19. Po drugiej wojnie światowej wyżej wymienieni za wspomnianą zbrodnię stanęli przed

${ }^{15}$ Marian Tadeusz Mazur („Bończa”), Szumiały nam świętokrzyskie jodty, Katowice [1992], s. 131.

${ }^{16}$ AIPN, GK, 411/216, Protokół przesłuchania podejrzanego Władysława Kolasy z 3 VI 1949, k. 129-130. Władysław Kolasa zeznał ponadto, że latem 1943 r. popełniono morderstwo na małżeństwie Chai i Ałte Goldmanach, przy torach kolejowych pomiędzy Grójcem a Brzustową, gm. Ćmielów. Morderstwa tego mieli dokonać członkowie AK z Ostrowca: Marian Błażejewski „Maria”, Jerzy Skwarek „Luks”, Czesław Szymański „Wiara”, Jerzy Żak i Zygmunt Nowakowski „Ładny” (ibidem, k. 131).

${ }^{17}$ W Goździelinie mieszkała rodzina Cytrynbaumów. Ich imiona udało się ustalić na podstawie bazy ofiar Holokaustu zamieszczonej na stronie internetowej Instytutu Yad Vashem. Frajda urodziła się w 1914, Rywka w 1884, Dovid w 1872, Mosze w 1917, a Dawid w 1882 r. W miejscowości tej mieszkała ponadto rodzina Morgenów (Bluma, Szmuel i jedna osoba o nieznanym imieniu) oraz Weinrybów (Izaak, Aron i Chaja) oraz Hena Grosman. Zob.: http://www.yadvashem.org/wps/portal/!ut/p/_s.7_0_A/7_0_FL?last_ name=\&first_name=\&location=Gozdzielin\&next_form=results, dostęp 30 VIII 2011 r. Por. także przypis 60 .

${ }^{18}$ Archiwum Instytutu Pamięci Narodowej Oddział w Lublinie Delegatura w Radomiu (dalej AIPN Ra), 29/138, Zeznanie świadka Marii Czuby z 7 III 1959 r., k. 64.

${ }^{19}$ AIPN Ki, 9/124, t. 1, Protokół przesłuchania podejrzanego Jana Szpinka z 25 II 1951 r., k. 255; zob. także akta z procesu: AIPN Ki, 9/124, t. 4, k. 51-53, 55, 94-101, 169-171. 
sądem. W uzasadnieniu wyroku Sądu Najwyższego z 6 marca 1958 r., uchylającego wyrok sądu pierwszej instancji skazujący Jana Szpinka „Motyla” na 10 lat więzienia, czytamy, że wyrok opierał się jedynie „na wyjaśnieniach i zeznaniach świadka Stanisława Tworka”, które „nie mogły stanowić dostatecznego i przekonywającego dowodu co do winy oskarżonego"20. W aktach nie znajdujemy protokołu z ekshumacji. Mieli jej dokonać i przenieść zwłoki ofiar na cmentarz żydowski członkowie rodziny Cytrynbaumów z Goździelina, o czym zeznał sołtys Goździelina Marceli Sternik (zob. dokument nr 3, s. 433-434).

W marcu 1944 r. w poczet oddziału „Barwy Białe” został włączony liczący 25 osób oddział „Rogatych”, który skupiał partyzantów AK z Podobwodu Ostrowiec Świętokrzyski (kryptonim „100”) ${ }^{21}$. Tym samym stan liczebny oddziału został podwojony. Wkrótce jednak ujawniły się tarcia pomiędzy „Toporem” a podległymi mu partyzantami. „Po prostu - wspominał Tadeusz Mazur „Bończa” - nie miał on z ludźmi wspólnego języka i nie umiał się do nich zbliżyć, co w warunkach partyzanckich miało jednak dość zasadnicze znaczenie”22. Te lub inne względy zadecydowały, że 20 maja Pietrzykowski został odwołany przez nowego komendanta Obwodu Opatów AK Jana Wojciechowskiego („Aisa”, „Młodziana”), a nowym dowódcą został Kazimierz Olchowik „Zawisza”. Pod koniec maja do oddziału dołączył też między innymi „Grzegorz” - Edward Sternik.

Olchowik urodził się 23 stycznia 1910 r. w Grodnie. Jak na realia Drugiej Rzeczypospolitej był osobą wykształconą - po maturze zdanej w Państwowym Gimnazjum Męskim im. Adama Mickiewicza w Grodnie przez trzy trymestry studiował na Wydziale Lekarskim Uniwersytetu Stefana Batorego w Wilnie. Przed wojną pracował w więziennictwie (zob. biogram na końcu tekstu). Poza obowiązkową służbą wojskową odbył wiele ćwiczeń i kursów wojskowych, dzięki czemu już 1 stycznia

${ }^{20}$ AIPN Ki, 9/124, t. 4, k. 169-171. „Zeznania św[iadka] Tworka ps. «Jaszczurka» - czytamy w uzasadnieniu wyroku - ze śledztwa VI.R.135/51 i jego wyjaśnienia w sprawie VI.R.129/51, na których oparły się sądy wyrokujące w sprawie niniejszej, nie wydają się wiarygodne z uwagi na zawarte $\mathrm{w}$ nich istotne rozbieżności. $\mathrm{Z}$ wyjaśnień Tworka ps. «Jaszczurka» ze śledztwa W sprawie VI.R.129/51/k. 142 oraz z jego zeznań ze śledztwa w sprawie VI.R.135/51 na k. 48 wynikałoby, że Tworek dowiedział się o wydaniu przez Szpinka rozkazu likwidacji Żydów wprost od Szpinka, natomiast na rozprawie w sprawie VI.R.129/51/k. 364 oraz w śledztwie w sprawie VI.R.135/51 przy konfrontacji ze Szpinkiem (k. 263) św[iadek] Tworek podał, że o wydaniu przez Szpinka rozkazu zlikwidowania Żydów dowiedział się od Mroczka, a nie bezpośrednio od samego Szpinka. W tej ostatniej relacji Tworek ps. «Jaszczurka» występuje jako tylko pośredni świadek na powyższą okoliczność. Bezpośrednim bowiem świadkiem jest wspomniany Mroczek, który nie był w ogóle przesłuchiwany w sprawie. Sprawdzenie tej okoliczności poprzez przesłuchanie bezpośredniego świadka Mroczka nie jest możliwe, ponieważ on nie żyje już od 1946 r.” (ibidem, k. 170).

${ }^{21}$ Mazur, Szumiały nam świętokrzyskie jodty, s. 131.

${ }^{22}$ Ibidem, s. 132. 
1935 r. awansował na podporucznika rezerwy ${ }^{23}$. Brał udział w kampanii wrześniowej, 9 września 1939 r. miał zostać awansowany na porucznika. Nominacja ta, którą ogłosić miał podobno dowódca pułku ppłk Antoni Żółkiewski, była uważnie weryfikowana przez Główną Komisję Weryfikacyjną AK w Niemczech ${ }^{24}$. Wątpliwości budził fakt, że wręczono ją w okresie, kiedy pułk znajdował się w głębokiej defensywie; dzień później 5. Pułk Strzelców Podhalańskich przestał praktycznie istnieć, a sam Olchowik dostał się do niewoli niemieckiej. Po zwolnieniu 27 października przyjechał do Ćmielowa, gdzie mieszkała rodzina jego brata Leona (1907-1940), posterunkowego Policji Państwowej w Opatowie, więźnia Ostaszkowa, zamordowanego wkrótce potem przez NKWD w Kalininie (dziś Twer) ${ }^{25}$.

W Ekspozyturze (Oddziale) II Okręgu Radom AK od 1942 r. Olchowik organizował wywiad i bojówkę. „W lutym 1944 r. - czytamy we własnoręcznie napisanym przezeń życiorysie - zostaję aresztowany przez gestapo i przebywam w więzieniu w Ostrowcu, skąd cudem wprost zostaję zwolniony"26. Szczegóły tego zwolnienia budziły w tym czasie spore emocje, o czym pisał jeszcze w czasie okupacji Zwiejski $^{27}$, a po wojnie zeznawał Kolasa ${ }^{28}$. Bezpośrednio po wyjściu z więzienia Olchowik

${ }^{23}$ Ryszard Rybka, Kamil Stepan, Awanse oficerskie w Wojsku Polskim 1935-1939, Kraków: Fundacja Centrum Dokumentacji Czynu Niepodległościowego, 2003, s. 98.

${ }^{24}$ Studium Polski Podziemnej (dalej SPP), KW 1, Weryfikacja żołnierzy AK, Teczka Kazimierza Olchowika, b.p.

${ }^{25}$ Naznaczeni piętnem Ostaszkowa. Wykazy jeńców obozu ostaszkowskiego i ich rodzin, oprac. Zuzanna Gajowniczek, Bernadetta Gronek, red. Wanda Chudzik, Warszawa: Rytm, 2000, s. 223.

${ }^{26}$ SPP, KW 1, Weryfikacja żołnierzy AK, Teczka Kazimierza Olchowika, Życiorys, k. 2 (rękopis).

27 „Około 18 II br. w komórce ZWZ w Mominie przebywało - pisał 24 II 1944 r. Zwiejski - dwu członków [o] pseud[onimach] Wyrwa i Zawisza. Około południa przybył do M[ominy] patrol w sile 3 żand[armów] i paru granatowych. Członkowie miejscowi, widząc żand[armów,] rzucili się do ucieczki. Żand[armi] otworzyli ogień. Dwaj ww. osobnicy zbiegli za stodołę. Widząc to, żand[armi] otoczyli stodołę i ujęli tych osobników. Wprowadzili ich do mieszkania naszego członka, mieszkającego w jednym budynku z tym panem, u którego byli schwytani osobnicy. Po lekkim pobiciu zabrano ich do Ostr[owca]. Zabrano od nich broń krótką i granaty. Chciano również zabrać naszego czł[onka,] lecz wstawił się za nim granatowy, stwierdzając, że nie ma on nic wspólnego ze schwytanym osobnikiem. Trzeciego dnia obaj osobnicy zostali wypuszczeni i przybyli do tego samego pana w Mom[inie]. Tam oświadczyli, że zostali wypuszczeni na tej podstawie, iż podali się za członków org[anizacji] polskich zwalczających komunistów, bolszewików i bandytów. Wrócili z bronią, którą im Niemcy zwrócili” (AZHRL, MiD III/18, Przejawy współpracy z Niemcami, k. 1 [odpis]).

${ }^{28}$ „Po dołączeniu do oddziału opowiadał, że był złapany przez gestapo w Ostrowcu, gdzie siedział około 2-ch tygodni, po czym został zwolniony wraz z «Wyrwą», gdyż z nim został złapany. Nadmieniam, że gestapo zwolniło go, oddając mu broń, gdyż powiedział, że jest kolegą «Mruka» [...]. Po demobilizacji II-ej dyw[izji] AK w końcu miesiąca grudnia $1944 \mathrm{r}$. był u mnie w domu «Zawisza», po cywilnemu i pokazywał mi broń palną syst[emu] «Parabellum» oraz przepustkę na niniejszą broń pisaną po niemiecku, która wydana była przez gestapo w Ostrowcu” (AIPN Ki, 013/24 (27/III), t. 1, k. 73). 
wstąił do oddziału „Barwy Białe”29; najpierw był oficerem wyszkolenia, a następnie został dowódcą oddziału. Od początku zyskał sobie duże poważanie wśród partyzantów. Tadeusz Mazur zanotował: „Oderwaliśmy się od «Topora», a nowego dowódcę, «Zawiszę», od początku obdarzyliśmy naprawdę wielkim zaufaniem. Mogę też z pełnym przekonaniem powiedzieć, że już w późniejszym okresie przekształciło się ono w wielkie obopólne przywiązanie. «Zawisza» rozumiał swoich żołnierzy i umiał z nimi właściwie postępować, co wcale nie oznaczało, że był pobłażliwy i niewymagający - wręcz przeciwnie, dyscyplina w oddziale znacznie wzrosła" ${ }^{30}$.

Oddział „Barwy Białe” do sierpnia 1944 r. działał głównie na terytorium powiatu opatowskiego. Cechowała go znaczna mobilność, a przede wszystkim rósł w siłę. W tym czasie jego stan liczebny zbliżył się do dwustu nieźle wyszkolonych żołnierzy. Oddział przeprowadził wówczas kilkanaście większych i mniejszych akcji zbrojnych, w których miało zginąć kilkunastu Niemców ${ }^{31}$.

Cieniem na dowódcy oddziału „Barwy Białe” kładzie się jego niezrozumiała, wręcz patologiczna nienawiść do Żydów. Świadczy o niej następujący incydent: pod koniec czerwca 1944 r. (w dzień Bożego Ciała?) powziął on podejrzenie, że lekarz w jego oddziale, ppor. WP „Miś” (nieustalonego nazwiska - być może Jaśkowicz lub Joskowicz), jest Żydem ${ }^{32}$. Na rozkaz Olchowika wezwano lekarza ze Śmiłowa-Binkowic, który przeprowadził „badanie”. Odbyło się ono w kwaterze „Zawiszy”, w obecności dowódcy oddziału, jego zastępcy Romana Rożyńskiego „Roga” i Edwarda Sternika „Grzegorza”33. Temu ostatniemu, po werdykcie, który oznaczał wyrok śmierci dla „Misia”, powierzono jego wykonanie. Wraz z „Jeleniem” (Janem Śledziem), „Toporkiem” (Henrykiem Wierzbińskim), „Wyrwą” (Zbigniewem Zawartko) i „Bystrym” (Zygmuntem Sieńkiem) załadowali skazanego na furmankę, udali się w kierunku lasu i tam go zastrzelili. Jak zeznawali oskarżeni, „Miš” przebywał w oddziale około miesiąca, w każdym razie był już w nim, kiedy dowódcą został Olchowik. Za mord na „Misiu” zapadły trzy wyroki skazujące - na Edwarda Sternika, Jana Śledzia i Henryka Wierzbińskiego (informacje o wyrokach zob. biogramy na końcu tekstu).

W ramach akcji „Burza” oddział „Barwy Białe” wszedł w skład 2. pp Leg. AK jako 5. kompania 2. batalionu. W okolice wsi Łagowica-Pipała, wyznaczony rejon koncentracji, „Zawiszacy” przybyli 2 sierpnia 1944 r. ${ }^{34}$ Oddziały partyzanckie, które weszły w skład 2., 3. i 4. pp Leg. AK, utworzyły 2. Dywizję Piechoty Legionów AK

${ }^{29}$ SPP, KW 1, Weryfikacja żołnierzy AK, Teczka Kazimierza Olchowika, Życiorys, k. 2; Mazur, Szumiały nam świętokrzyskie jodty, s. 131.

${ }^{30}$ Mazur, Szumiały nam świętokrzyskie jodty, s. 131, 137.

${ }^{31}$ Borzobohaty, ,Jodta”..., s. 197.

${ }^{32}$ AIPN Ki, 126/117, Protokół przesłuchania podejrzanego Henryka Wierzbińskiego z 6 XII 1949 r., k. 29-32.

${ }^{33}$ AIPN, GK, 411/216, Protokół przesłuchania podejrzanego Edwarda Sternika z 8 VI 1949 r., k. 171.

${ }^{34}$ Sierant, 2 Pułk Piechoty Legionów..., s. 81. 
„Pogoń”, pod dowództwem płk. Antoniego Żółkiewskiego „Lina”. Po żądaniu gen. Mitrofanowa (a nie Muratowa, jak się powszechnie uważa), aby oddziały Armii Krajowej przeszły na tyły Armii Czerwonej, 9 sierpnia 2. pp Leg. AK przemieścił się na północną stronę Gór Świętokrzyskich i zajął pozycje od wsi Kraszków po Jeleniów. Dwa dni później, wieczorem 11 sierpnia, pułk przeniósł się w rejon wsi JeziorkoDębno-Wola Szczygiełkowa-Brandys. Nocą z 15 na 16 sierpnia - realizując rozkaz gen. Bora-Komorowskiego wzywający do marszu na pomoc walczącej Warszawie (akcja o kryptonimie „Zemsta”) - 2. pp Leg. AK przesunął się do wsi Siekierno ${ }^{35}$.

Podczas postoju w tej wsi żołnierze z oddziału „Barwy Białe” złapali w lesie czterech Żydów, którzy poszukiwali żywności ${ }^{36}$. Doprowadzeni zostali do Olchowika; w ten sposób dowiedział się on, że w lasach siekierzyńskich przebywa grupa od 30 do 58 Żydów ${ }^{37}$, uciekinierów z obozu pracy w Skarżysku-Kamiennej, należącego do koncernu zbrojeniowego HASAG ${ }^{38}$. Obozy pracy przymusowej zlokalizowane w dystrykcie radomskim i pracujące głównie na potrzeby przemysłu zbrojeniowego likwidowane były w tym czasie pośpiesznie w związku z szybko postępującą ofensywą Armii Czerwonej. Sytuacja ta stwarzała pewne warunki do ucieczki z obozów tuż przed ich likwidacją lub w jej trakcie. Uciekinierzy szukali schronienia w dużych kompleksach leśnych, wielu zetknęło się wówczas z operującymi na ich terenie oddziałami partyzanckimi wszystkich niemalże formacji. Dziś wiemy już, w wyniku badań ostatnich lat, że w wielu wypadkach taki kontakt kończył się dla Żydów tragicznie. O uciekinierach z obozu w Starachowicach pisał ostatnio także Christopher Browning ${ }^{39}$, choć autorowi nieznane były materiały powojennych procesów karnych, dzięki którym poznajemy szczegóły tych ponurych zbrodni.

Wróćmy jednak do wydarzeń z sierpnia 1944 r. Olchowik po przesłuchaniu zatrzymanych Żydów polecił Sternikowi zorganizowanie „likwidacji” uciekinierów. Do ich obozowiska udało się około 60 ludzi z oddziału „Barwy Białe”; trasę wyjawili im najprawdopodobniej niczego nieświadomi Żydzi schwytani wcześniej. Potem nastąpiła egzekucja, której przebieg przytoczyliśmy na początku niniejszego

${ }^{35}$ Ibidem, s. 114 .

${ }^{36}$ AIPN Ki, 126/45, k. 93.

${ }^{37}$ Liczby skrajne, które padają w zeznaniach oskarżonych.

${ }^{38}$ Ogromny, prywatny koncern zbrojeniowy Hugo Schneider Aktiengesellschaft (HASAG) rozmieścił na terenie GG kilka fabryk prochu i amunicji. Były to: Skarżysko-Kamienna, Kielce i cztery zakłady w Częstochowie. Całkowita liczba zatrudnionych tam w latach 1942-1945 żydowskich więźniów wynosiła ponad 42 tys. Część robotników przed końcem wojny deportowano do obozów koncentracyjnych Buchenwald, Gross-Rosen i Ravensbrück oraz do Lipska, macierzystej siedziby HASAG. Fabrykę HASAG w Skarżysku zlikwidowano w lipcu 1944 r., niektórym więźniom udało się wówczas zbiec do pobliskich lasów. Por. Jacek Wijaczka, Grzegorz Miernik, Żydowscy robotnicy przymusowi w zakładach zbrojeniowych HASAG w Generalnym Gubernatorstwie w czasie II wojny światowej [w:] Z przeszłości Żydów polskich. Polityka - gospodarka - kultura - społeczeństwo, red. Jacek Wijaczka, Grzegorz Miernik, Kraków: IPN, 2005, s. 181-203.

${ }^{39}$ Christopher R. Browning, Remembering Survival. Inside a Nazi Slave-Labor Camp, New York: W.W. Norton \& Company, 2010. 
artykułu. Była tak drastyczna, że nawet niektórzy członkowie ekspedycji nie byli w stanie jej oglądać. Buty i ubrania ofiar trafiły jeszcze tego samego dnia do oddziału „Zawiszy”. Kilkanaście dni później, 1 września 1944 r., Olchowik został odwołany ze stanowiska dowódcy 5. kompanii i przeniesiony do dowództwa 2. Dywizji AK jako oficer łącznikowy ${ }^{40}$. Czy decyzja ta miała związek z wydarzeniami w Siekiernie? Wszystko wskazuje, że tak, choć trudno o potwierdzenie źródłowe tego przypuszczenia. Po rozwiązaniu 2. pp Leg. AK Olchowik został wyznaczony na dowódcę 2. batalionu z zadaniem przeprowadzenia i rozformowania go w rejonie Gór Świętokrzyskich.

Kilka lat później Sąd Apelacyjny w Kielcach za zbrodnię w Siekiernie osądził i skazał kilka osób: Władysława Kolasę, Edwarda Sternika, Jana Śledzia, Jana Górskiego, Stanisława Kaweckiego i Jana Steca (zob. biogramy na końcu tekstu). W uzasadnieniu wyroku czytamy: „Jak wynika z ich wyjaśnień, linia postępowania ich dowódców i działalność zbrodnicza ich samych pozostawała w sprzeczności z niezatraconymi w zupełności uczuciami i pojęciami humanitaryzmu - ale tylko względem swych własnych rodaków, natomiast odpowiadało im mordowanie Żydów, których nie uważali za swych braci [...]"41.

18 sierpnia oddział „Barwy Białe” udał się z Siekierna w kierunku Przysuchy, nowego rejonu koncentracji 2. Dywizji Piechoty. 27 sierpnia 1944 r. - wobec konieczności sforsowania niemieckich umocnień na Pilicy - gen. „Bór” wstrzymał marsz na Warszawę i nakazał realizację zadań wynikających z planu „Burza”. Dowódca 2. DP płk „Lin” Żółkiewski rozkazem z 12 października rozwiązał 2. pp Leg. AK jako jednostkę taktyczną ${ }^{42}$. Poszczególne kompanie, w tym żołnierze 5. kompanii 2. batalionu, powróciły na teren swego pochodzenia, czyli do powiatu opatowskiego. W tym czasie por. Michniewicz „Wyrwa”, dowódca plutonu saperów, zastrzelił z automatu trzech Żydów, którzy byli woźnicami przy 2. pp Leg. AK . „Zabójstwo to widziałem na własne oczy - zeznał Władysław Kolasa - a potwierdzić może każdy czł[onek] AK z oddz[iału] "Zawiszy»"43. Zbrodnia ta nigdy nie została osądzona. Ręka sprawiedliwości nie dosięgła także osób najważniejszych - Kazimierza Olchowika i sierżanta o pseudonimie „Bolrok”, których sumienie obciąża śmierć licznych niewinnych istnień ludzkich. Po drugiej wojnie światowej Olchowik przedostał się przez Niemcy do Anglii, a stamtąd wyjechał do Australii, gdzie zmarł w 1979 r. ${ }^{44}$ O losie „Bolroka”, niestety, nic nie wiemy.

${ }^{40}$ SPP, KW1, Werfikacja żołnierzy AK, Teczka Kazimierza Olchowika, Zaświadczenie weryfikacyjne, k. 1.

${ }^{41}$ AIPN, GK, 217/45, k. 219.

${ }^{42}$ Sierant, 2 Putk Piechoty Legionów..., s. 232.

${ }^{43}$ AIPN, GK, 411/216, Protokół przesłuchania podejrzanego Władysława Kolasy z 10 II 1949, k. 102.

${ }^{44}$ Mazur, Szumiaty nam świętokrzyskie jodty, s. 228. 
O mordach dokonanych przez partyzantów z oddziału „Barwy Białe” na Żydach w Goździelinie, Lisowie i lasach siekierzyńskich próżno szukać informacji w literaturze przedmiotu. Nawet w wydanej w latach dziewięćdziesiątych XX w. szczegółowej i skrupulatnie opracowanej monografii 2. pp Leg. AK autorstwa Piotra Sieranta nie ma na ten temat ani słowa. Jedynie Bogdan Hillebrandt w monografii poświęconej partyzantce na Kielecczyźnie - a konkretnie w jednym z przypisów - wspomniał o zbrodni w lasach siekierzyńskich, zaniżając liczbę ofiar do pięciu ${ }^{45}$. Transformacja ustrojowa w Polsce spowodowała, że zaczęły się pojawiać opracowania, które odsłaniają odmienny obraz polskiej konspiracji, szczególnie w odniesieniu do zagłady polskich Żydów. Ważnym tekstem był artykuł Jadwigi Karolczak, opublikowany w świątecznym wydaniu „Słowa Ludu”, traktujący o zbrodni w Zagórzu pod Daleszycami dokonanej przez członków oddziału AK „Wybranieccy”46. Autorka wspomniała w nim między innymi o mordzie w lasach siekierzyńskich dokonanym przez inny oddział AK o charakterystycznej nazwie „Barwy Białe”.

Prezentujemy dalej fragmenty tekstów źródłowych z licznych materiałów dochodzeniowo-śledczych i procesowych z zasobu archiwalnego Instytutu Pamięci Narodowej. Odnaleźliśmy materiały śledcze i prokuratorskie dotyczące Stanisława Różalskiego ${ }^{47}$, Władysława Kolasy ${ }^{48}$, Kazimierza Borkowskiego ${ }^{49}$ (członka opatowskiej „dwójki” AK), Aleksandra Zalewskiego ${ }^{50}$ oraz innych $^{51}$; akta spraw karnych Wojskowego Sądu Rejonowego przeciwko Władysławowi Kolasie ${ }^{52}$ oraz teczkę personalną Stanisława Tworka ${ }^{53}$ (TW „Kot”). Najważniejsze materiały pochodzą jednak z akt procesu karnego prowadzonego przed Sądem Apelacyjnym w Kielcach, w którym osądzono: Władysława Cybulę, Jana Górskiego, Stanisława Gruszkę, Stanisława Kaweckiego, Władysława Kolasę, Stanisława Kryja, Franciszka Łabuza, Stanisława Markiewicza, Ryszarda Nowackiego, Jana Steca, Edwarda Sternika, Jana Śledzia, Henryka Wierzbińskiego i Aleksandra Zalewskiego ${ }^{54}$, oraz z procesu Stanisława Różalskiego ${ }^{55}$. Korzystaliśmy ponadto $\mathrm{z}$ akt śledczych oraz akt procesu

\footnotetext{
${ }^{45}$ Hillebrandt, Partyzantka na Kielecczyźnie..., s. 293.

${ }^{46}$ Jadwiga Karolczak, Duchy i upiory, „Słowo Ludu. Magazyn”, 21 VIII 1991, s. 6. Na ten temat zob. opracowanie Aliny Skibińskiej i Joanny Tokarskiej-Bakir, „Barabasz” i Żydzi. $Z$ historii oddziatu $A K$,Wybranieccy” w tym tomie.

${ }^{47}$ AIPN Ki, 013/3635 (5422/III).

${ }^{48}$ Ibidem, 8/806 (SR 499/49); ibidem, 027/21 (27/III mf 22/3).

${ }^{49}$ AIPN Ra, 109/4.

${ }^{50}$ AIPN, GK, 411/216, cz. 1-2, Prokuratura Sądu Okręgowego w Kielcach.

${ }^{51}$ AIPN Ki, 013/24 (27/III), t. 1-2; ibidem, 013/25.

52 Ibidem, 8/806 (SR 499/49); ibidem, 126/48.

${ }^{53}$ Ibidem, 005/358 (2580/I).

${ }^{54}$ AIPN, GK, 217/45-47, 47a.

${ }^{55}$ AIPN Ra, 29/138.
} 
karnego członków opatowskiej „dwójki” AK: Władysława Banaszka, Zenona Krzekotowskiego, Michała Pytlaka, Józefa Radomskiego i Jana Szpinka ${ }^{56}$. Wyroki zapadłe w tych sprawach przytoczone zostały w notach biograficznych kończących opracowanie.

\section{MATERIAŁY ŹRÓDŁOWE}

\section{Goździelin, marzec lub kwiecień 1943 r.}

\section{Świadkowie}

1. Zeznanie świadka Marii Czuby ${ }^{57}$

W czasie okupacji mieszkałam w samotnym domu za wsią Goździelin koło tzw. dołów, których nazwa pochodzi od znajdujących się w pobliżu jarów. W jarach tych sama widziałam, jak ukrywali się po wysiedleniu Żydzi. Nazwisk tych Żydów nie znałam, wiem, że na jednego z nich mówiono „Majurek”, był gruby. W marcu czy kwietniu 1943 r. wieczorem, daty bliżej nie pamiętam, przyszło do mojego domu kilku uzbrojonych mężczyzn, ubranych po cywilnemu, którzy kazali mi się natychmiast odwrócić twarzą do ściany domu, co uczyniłam, widząc u nich broń. Jeden z osobników tych, wysoki, czarny, w kapeluszu, mówił ochrypłym głosem i stał przy mnie z bronią i zapowiedział mi, że jak się będę oglądać, to mnie zastrzeli. W tym czasie zgasili oni $\mathrm{w}$ domu światło. Tak stojąc pod ścianą, po kilku minutach usłyszałam, że inni osobnicy przyprowadzili do domu kilka innych osób, których ustawili pod przeciwną ścianą w domu i zaczęli wołać do nich o pieniądze. Jak zorientowałam się, przyprowadzonymi osobami byli Żydzi, którzy ukrywali się w dołach za moim domem, gdyż poznałam wtedy po głosie wspomnianego „Majurka" i jedną Żydówkę, która z nim chodziła. Ilu tych Żydów było, nie wiedziałam z powodu, że stałam pod ścianą odwrócona do nich tyłem. Zrozumiałam tylko, że Żydzi ci oddali im posiadane pieniądze, bo słyszałam, jak Żydówka, która chodziła z „Majurkiem”, mówiła, że więcej nie ma pieniędzy. Po zabraniu pieniędzy bandyci ci przyprowadzonych Żydów rozstrzelali w moim domu pod ścianą, a odchodząc, podpalili dom, który się doszczętnie spalił. Drugiego dnia po tym wypadku przyjechali do mnie Niemcy i pytali się, czy ja tych Żydów przechowywałam, oraz kto ich zabił.

2. Zeznanie Marii Czuby na rozprawie głównej ${ }^{58}$

Podczas okupacji ukrywałam Żydów u siebie w domu. Było to w roku 1943 na wiosnę, daty dokładnie nie pamiętam, gdy do mego domu zaczął się ktoś dobijać.

${ }^{56}$ AIPN Ki, 9/123; ibidem, 9/126.

${ }^{57}$ AIPN, GK, 411/216, Protokół przesłuchania z 9 VIII 1949 r. w WUBP w Kielcach, oficer przesłuchujący Marian Duda, k. 30-31.

${ }^{58}$ AIPN, GK, 217/45, Protokół rozprawy głównej przed Sądem Apelacyjnym w Kielcach w dniach 21-23 II 1950 r., k. 97-98. 
Otworzyłam i do mieszkania wszedł wysoki mężczyzna. Nie wiem, czy miał on karabin, kazał mi natychmiast zaświecić lampę i zasłonić okno. W drzwiach stała Żydówka, która się u mnie ukrywała, gdy ona chciała zasłonić to okno, mężczyzna odsunął ją i sam je zasłonił, rozkazując mnie jednocześnie nie oglądać się i nie patrzeć w okno. Odwróciłam się do ściany i tak stałam, a za sobą w tym czasie słyszałam tylko tupot. Nie wiem, ilu ludzi potem weszło jeszcze do mieszkania, bo cały czas stałam odwrócona do ściany. Słyszałam tylko jęki Żydów i głosy ich: „panie, panie, przecież my Polacy”. Przy mnie stał cały czas jakiś jeden mężczyzna, który potem kazał mi się patrzeć za piec. Jeden z mężczyzn 2 razy krzyknął do Żydów, aby dali pieniądze, Żydzi dawali, a ten wysoki, który stał koło mnie, zapytał, ile dali, drugi odpowiedział mu na to, że za mało, na co Żydzi odpowiedzieli, że więcej już nie mają, wówczas dopiero usłyszałam strzały. Ilu było w tym czasie Żydów w mieszkaniu, nie wiem, nie oglądałam się za siebie, tak byłam zalękniona. Słyszałam jeszcze, jak jeden z mężczyzn pytał drugiego, czy brać ten pakunek. O jaki to pakunek chodziło, nie wiem. Potem mężczyzna, który mnie pilnował, kazał mi się odwrócić od pieca i powiedział: „a teraz uciekajcie kobieto, bo jutro przyjdą Niemcy i zabiją was. Wyszłam zaraz z mieszkania, udałam się na groblę i tam kilkanaście minut przeleżałam na pół przytomna. Gdy się podniosłam, to już dom się palił. Ludzie ci nie kazali mi przed tym wynosić żadnych rzeczy z mieszkania. Kto podpalił dom, nie wiem. Nie pamiętam, czy po moim wyjściu z mieszkania któryś z nich jeszcze został w nim, czy ja wychodząc, byłam ostatnia. Byłam wtedy zupełnie nieprzytomna i może nie zwróciłam nawet na to uwagi. [...] Od chwili mego wyjścia z mieszkania do chwili pożaru upłynęło może z pół godziny. Nie wiem, kto zawiadomił Niemców o tym wypadku u mnie, ja tego nie meldowałam.

\section{Zeznanie Marcelego Sternika ${ }^{59}$}

W czasie okupacji niemieckiej byłem sołtysem wsi Goździelin. Wypadek pomordowania osób narodowości żydowskiej w domu Czuby Marii i spalenie jej domu miało miejsce wiosną 1943 r. w nocy, daty bliżej nie pamiętam. O wypadku spalenia domu dowiedziałem się dopiero drugiego dnia, kiedy przyszli do mnie żandarmi niemieccy, aby ich na miejsce to zaprowadzić. Udając się z żandarmerią na miejsce, zastałem spalony dom, w zgliszczach którego rozeznano siedem spalonych trupów ludzkich, z czego jeden wyglądał na trupa małego dziecka, a pozostałe na dorosłych. Niemcy pytali się Czubiny, kto zabił tych ludzi i co to byli za ludzie, na co Czubina odpowiedziała, że byli to Żydzi i zabili ich jacyś osobnicy ubrani po cywilnemu oraz spalili jej dom. Trupy te z polecenia Niemców zakopane zostały w dole od kartofli zaraz za spalonym domem, gdzie leżały do wiosny 1945 r., tj. do czasu aż z miejsca tego zabrali ich nieznani osobnicy narodowości żydowskiej

${ }^{59}$ AIPN, GK, 411/216, Protokół przesłuchania z 9 VIII 1949 r. w WUBP w Kielcach, oficer przesłuchujący Marian Duda, k. 28-29. 
z Bodzechowa i rodzina Cytrynbaumów z Goździelina ${ }^{60}$, która prawdopodobnie obecnie mieszka w Krakowie, bliższego adresu nie znam.

\section{Zeznanie Marcelego Sternika na rozprawie głównej ${ }^{61}$}

Wtedy to zobaczyłem te trupy. Było ich zdaje się 7, ale same już tylko szkielety, 6 było większych, a jeden był mały. [...] Ja musiałem się z rozkazu Niemców zająć zagrzebaniem tych szkieletów. Przed tym jeszcze Niemcy kazali poprzerzucać spalone szmaty, z których wyjęli dwa zwitki dolarów, ale ponieważ były one przepalone i nic już nie warte, zostawili je, a potem dzieci ze wsi bawiły się nimi.

\section{Zeznanie Józefa Radomskiego ${ }^{62}$}

W okresie okupacji nikt mi nie meldował o ukrywaniu się Żydów we wsi Goździelin gm. Bodzechów i ja nie wiedziałem, że ukrywają się tam Żydzi. Gdzieś w 1943 r. słyszałem o dokonaniu morderstwa Żydów we wsi Goździelin. [...] Stwierdzam kategorycznie, że morderstwo Żydów w Goździelinie było dokonane bez mojej wiedzy. Nikomu polecenia dokonania tego morderstwa nie dawałem. Jest nieprawdą, by Różalski otrzymał ode mnie polecenie-rozkaz dokonania morderstwa Żydów w Goździelinie.

\section{Oskarżeni}

6. Zeznanie Stanisława Tworka ps. „Jaszczurka”63

Wiosną 1943 r. Mroczek Stanisław dowiedział się, lecz jaką drogą, tego nie wiem, że we wsi Goździelin u jednej kobiety na którą wołają „królica”, przechowuje się kilku Żydów. O powyższym fakcie zameldował Szpinkowi Janowi ps. „Motylowi”, który po przyjęciu meldunku rozkazał ich zlikwidować. Do likwidacji tych Żydów z terenu Bodzechowa wyznaczył mnie i Mroczka Stanisława i sam odjechał do Ćmielowa. Przez kogo zostali wyznaczeni ludzie z Ćmielowa, tego nie wiem, czy przez Szpinka, czy przez Radomskiego. Wyznaczeni z Ćmielowa do likwidacji

${ }^{60}$ Z Goździelina pochodził i przeżył wojnę Jankiel Cytrynbaum, ur. w 1910 r. (Archiwum Żydowskiego Instytutu Historycznego [dalej AŻIH], CKŻP, Wydział Ewidencji i Statystyki, Kartoteka Ocalałych z Zagłady). W dokumentach Komitetu Żydowskiego w Ostrowcu znajdujemy podanie Majera i Jankiela Cytrynbaumów, zam. w Ostrowcu, ul. Radomska 43 do Likwidatora Zarządu Państwowego w sprawie objęcia w posiadanie domu z ogrodem w Goździelinie, pod nr. 81 na mocy wyroku Sądu Grodzkiego w Ostrowcu z 12 V 1945 r., oraz pismo z 18 IV 1945 r. do Sądu Grodzkiego w Ostrowcu od tych samych osób, wtedy zamieszkałych w Denkowie, ul. Wesoła 13, w sprawie odzyskania szafy dębowej z lustrem od małżonków Eugenii i Jana Pronobisów z Goździelina, którzy odmawiają zwrotu (AŻIH, Komitet Żydowski w Ostrowcu Świętokrzyskim, 368/6).

${ }^{61}$ AIPN, GK, 217/45, Protokół rozprawy głównej przed Sądem Apelacyjnym w Kielcach w dniach 21-23 II 1950 r., k. 97.

${ }^{62}$ AIPN Ra, 29/138, Protokół przesłuchania z 17 III 1959 r. przez prokuratora wojewódzkiego w Kielcach Leona Śliwińskiego, k. 74.

${ }^{63}$ AIPN Ra, 109/4 k. 123-124. 
tej byli: Różalski Stanisław ps. „Grażyna”, Kolasa Władysław, Nowacki Ryszard, Cebula Władysław ps. „Grzmot” i Głębicki, którego imienia nie pamiętam. Wszyscy wymienieni zgłosili się do mieszkania Mroczka Stanisława i razem udaliśmy się do Goździelina. [...] Na drugi dzień ja i Mroczek Stanisław zostaliśmy wezwani przez Szpinka Jana do mieszkania Różalskiego Stanisława z Ćmielowa. W mieszkaniu tym Szpinek Jan zarządał [sic!] od nas sprawozdania z przeprowadzonej akcji, ponieważ rano zdążyliśmy się dowiedzieć, że w domu tym zostało spalone dużo materiałów i pieniędzy, przeto i o tym zameldowaliśmy Szpinkowi Janowi. Po odebraniu od nas sprawozdania Szpinek Jan począł czynić wymówki Różalskiemu Stanisławowi, że nie przeszukał dokładnie mieszkania i nie zabrał tych rzeczy, tylko pozwolił im się spalić.

\section{Zeznanie Władysława Kolasy na rozprawie głównej ${ }^{64}$}

Odnośnie [do] okoliczności zabójstwa 7 Żydów w Goździelinie gm. Bodzechów wyjaśniam, co następuje: wiosną 1943 roku otrzymałem rozkaz na piśmie od zastępcy dowódcy kompanii, abym sam pojedynczo udał się do Bodzechowa i tam czekał na przybycie „Grażyny”. Poszedłem więc i czekałem, a po pewnym czasie dołączyli do mnie Nowacki i Cybula. Następnie przyszedł do nas „Grażyna”, który był wówczas zastępcą dowódcy kompanii i powiedział nam, że mamy się udać z rozkazu - nie mówił z czyjego rozkazu - rozstrzelać Żydów. „Grażyna” był moim przełożonym, podlegałem „Grażynie” jako zastępcy dowódcy kompanii, byłem obowiązany jako żołnierz, który przysięgał posłuszeństwo swoim przełożonym wykonać rozkaz. Nowacki, który przyjechał wówczas razem z „Grażyną”, był mocno pijany, prowadził on rower. Przed tym z oskarżonym Nowackim nie widziałem się. Udaliśmy się wszyscy w kierunku, gdzie mieli być Żydzi. Po drodze otrzymałem pistolet systemu „Mauser”. Gdy doszliśmy do domu, w którym mieli być Żydzi, wtedy „Grażyna” i Mroczek, którzy też byli z nami, weszli do mieszkania, gdzie było 3-ch Żydów, reszta zaś Żydów sama wyszła z kryjówki i weszła do mieszkania. W tym czasie ja i Nowacki staliśmy na zewnątrz domu. Co działo się wewnątrz domu, nie wiem, bo nie widziałem. Ponieważ ja nie umiałem się obchodzić z pistoletem danym mi, Nowicki powiedział, że pokaże mi sposób obchodzenia się z nim i w tym celu weszliśmy do mieszkania. Gdy weszliśmy tam, to zauważyliśmy, że światło tam było zgaszone i leżało już zastrzelonych 7 osób, a jedna kobieta była żywa. Kto dokonał tego morderstwa, nie wiem, bo na własne oczy tego nie widziałem, ale chyba uczynił to „Grażyna”, bo on pierwszy wraz z Mroczkiem weszli do mieszkania, a gdy ja z Nowackim wszedłem to już było po wszystkim. Grażyna brał jeszcze ze stołu jakieś pieniądze, może 120-200 złotych, czy te pieniądze należały do Żydów, nie wiem. My domu potem nie spaliliśmy. [...] Jeśli chodzi o morderstwo Żydów w Bodzechowie, to działałem tam pod przymusem i na rozkaz, gdyż tak jak już powiedziałem, byłem żołnierzem, który składał przysięgę posłuszeństwa.

${ }^{64}$ AIPN, GK, 217/45, Protokół rozprawy głównej przed Sądem Apelacyjnym w Kielcach w dniach 21-23 II 1950 r., k. 81, 102-103. 
Gdybym otrzymał rozkaz bicia Żydów, nie mogę powiedzieć, co wtedy zrobiłbym, bo takiego rozkazu nie otrzymałem. [...]

Ja wtedy nie analizowałem tego rozkazu, gdyż jako żołnierz nie mogłem tego czynić. I dziś po dokładnym zanalizowaniu tego wiem, że biorąc rzecz z punktu widzenia żołnierskiego, musiałem tam iść i wykonywać rozkaz, choć z punktu widzenia ludzkiego i humanitarnego potępiam to i uważam za walkę bratobójczą. Już wtedy wiedziałem, że wydawać taki rozkaz to jest świństwo, byłem jednak wobec rozkazu bezsilny, gdyż składałem przysięgę posłuszeństwa i wierności i musiałem tej przysięgi dotrzymać i pozostać w jednej organizacji. Za niewykonanie rozkazu groziła mi kula w łeb, bo dwójka czuwała. Dwójki wszyscy bali się. Raz kwaterując w miejscowości Ujazd, komendant Topór widząc podchmielonego żołnierza, groził mu zastrzeleniem, taki był surowy, ostry i bezwzględny. Nie słyszałem, aby za przejście z jednego oddziału do innej organizacji zastrzelono kogoś, ale choć tego nie słyszałem, nie wykluczam, że tak mogło być, gdyż składało się przysięgę wierności tej właśnie organizacji. [...]

Żydów Hajgotów z Grójca zastrzelili jacyś ludzie z Ostrowca, którzy kwaterowali tam. Nie wykluczam, że była to grupa AK, która w międzyczasie przeszła do NSZ, wówczas kwaterowała tam AK.

\section{Zeznanie Ryszarda Nowackiego na rozprawie głównej65}

Wtedy gdy szliśmy do Bodzechowa likwidować tych 7 Żydów, byłem zupełnie pijany. Poszedłem tam na rozkaz „Grażyny”, któremu bezpośrednio podlegałem. Należałem wtedy do tzw. sekcji specjalnej. „Grażyna” wydając nam jakiś rozkaz, nie miał zwyczaju nigdy mówić, na jaką akcję i przeciw komu idziemy, mówił tylko, że idziemy na „robotę”. Nie zastanawiałem się nigdy nad tym z góry, na jaką robotę idziemy, tak samo było i wówczas. Przed tym wypiłem pewną ilość wódki, później jeszcze po drodze do Bodzechowa piłem razem z „Grażyną”, bo lubiłem wódkę. Po wypiciu wódki pojechaliśmy wieczorem do wsi Goździeliny, gdzie u wylotu wsi czekali na nas Kolasa, Cybula, Tworek i Mroczek. Wtedy dopiero po spotkaniu się z nimi „Grażyna” powiedział nam wszystkim, że idziemy likwidować Żydów, którzy się ukrywają we wsi. Nie pamiętam teraz dokładnie, czy wtedy rozdzielno między nas funkcje. Okrążyliśmy wtedy dom, ja stałem przed domem, a „Grażyna” i Mroczek weszli do wewnątrz domu. Żydzi sami powychodzili z kryjówki, było ich parę osób. Czy oprócz „Grażyny” i Mroczka wszedł jeszcze ktoś do mieszkania, nie pamiętam. Nie wiem, kto tam w mieszkaniu strzelał, bo przy tym nie byłem, stojąc przed domem, słyszałem tylko strzały. Domu potem nie podpaliliśmy. Poszedłem wtedy na tę akcję, ponieważ był to rozkaz, a ja byłem przyzwyczajony do tego, że rozkaz jest zawsze słuszny, byłem wtedy zresztą bardzo młody, a przy tym mocno pijany, od Bodzechowa już nie jechałem na rowerze, bo zataczałem się, tylko prowadziłem rower. [...] Wyjaśniam, że sekcja specjalna była to grupa ludzi

${ }^{65}$ AIPN, GK, 217/45, Protokół rozprawy głównej przed Sądem Apelacyjnym w Kielcach w dniach 21-23 II 1950 r., k. 81-82. 
podlegająca rozkazom dwójki. Ja należałem do tej sekcji przez czysty przypadek, ponieważ Robak wciągnął mnie do organizacji, a on był właśnie w dwójce, więc i ja się w niej znalazłem. [...] Nie wiem, dlaczego zostali zastrzeleni Żydzi w Goździelinie, ale dlaczego Żydzi nie mogliby popełnić jakiegoś czynu, za który powinni odpowiadać. I ja wówczas wierzyłem, że widocznie jakiś czyn popełnili i dlatego zostali zastrzeleni, dziś temu jednak nie wierzę. [...] Nie mówiłem nic w śledztwie o zabraniu pomordowanym Żydom jaki[ch]ś pieniędzy i o dzieleniu się nimi, nie wiem bowiem, czy w ogóle jakiekolwiek pieniądze były w ogóle wtedy zabierane i komu. O żadnym rabunku Żydów nie słyszałem.

\section{Zeznanie Władysława Cybuli na rozprawie głównej ${ }^{66}$}

W sprawie zabójstwa Żydów we wsi Goździeliny wyjaśniam, co następuje: do udziału w tym zabójstwie nie przyznaję się, a [w] każdym razie nie przyznaję się do winy, jedynie tylko do czynu. Nie pamiętam dokładnie, kiedy to było, ale otrzymałem rozkaz od Radomskiego - sekretarza gminy, że mam się stawić do wsi Brzóstowej. Polecił mi on zameldować się u „Grażyny”. Rozkaz ten wykonałem. Po zameldowaniu się u „Grażyny” ten powiedział mi, że mamy wykonać pewne zadanie, dał mi broń i kazał mi spotkać się z Mroczkiem na moście przy wsi, gdzie mieliśmy oczekiwać wspólnie na dalsze rozkazy. Na wspomnianym moście rzeczywiście spotkałem Mroczka, Kolasę i po pewnym czasie nadszedł też i „Grażyna”, który oświadczył nam, że idziemy w kierunku wsi Goździeliny, nie mówiąc jeszcze w dalszym ciągu po co. Był tam wtedy też oskarżony Nowacki, mocno pijany. Doszedłszy dopiero do samej wsi, usłyszałem od „Grażyny”, że przechowują się tu Żydzi, których mamy rozkaz zlikwidować, przy czym nie mówił on dlaczego. „Grażyna” z Mroczkiem weszli do mieszkania, a my reszta zostaliśmy na obstawie. Po pewnym czasie ja wszedłem do mieszkania i rzucając po nim okiem, zauważyłem w mieszkaniu około 4-5 osób i „Grażynę”, który ładował pistolet i zabierał się do strzelania. Zauważyłem jeszcze jakąś kobietę, która stała odwrócona do ściany, a obok niej stał Mroczek. Widząc „Grażynę” gotującego się do strzelania, natychmiast wycofałem się z mieszkania. Po jakimś czasie z mieszkania wyszedł „Grażyna”, który niósł pod pachą jakieś zawiniątko, poprosiłem go wtedy o zwolnienie mnie i udałem się zaraz do domu. Nie zauważyłem wtedy, wracając, żadnej łuny od pożaru, słyszałem potem we wsi, że sama kobieta - właścicielka domu - podpaliła w nocy dom. W pewien czas potem poszedłem do Różalskiego ps. „Grażyna” z zapytaniem, po co strzelali do tych Żydów. Powiedział mi na to, że taki był rozkaz, tylko że za dużo zużyto do tego amunicji i że lepiej by było stracić ich po cichu inaczej. To właśnie oficer śledczy przesłuchujący mnie zapisał. Nie rozumiałem wtedy dobrze tego czynu, miałem dopiero lat 21 i wierzyłem dowódcom, że to, co oni robią, jest dobre i słuszne. Że idziemy likwidować Żydów, dowiedziałem się o tym dopiero na miejscu, nie miałem czasu zastanawiać się nad tym, Żydzi w tym

${ }^{66}$ AIPN, GK, 217/45, Protokół rozprawy głównej przed Sądem Apelacyjnym w Kielcach w dniach 21-23 II 1950 r., k. 82. 
czasie byli już w mieszkaniu. Pierwsi do mieszkania weszli „Grażyna” i Mroczek, ja, Nowacki i Kolasa stali na zewnątrz domu na obstawie. Wszedłszy do mieszkania, żadnego dziecka tam nie widziałem. Mówił mi o tym dopiero oficer śledczy, że w tej liczbie było i jedno dziecko, dlaczego więc miałbym zaprzeczyć. Nie pamiętam także, czy Nowacki wszedł potem do mieszkania. Rozkazu tego, wydanego przez dowództwo oddziału, wtedy nie analizowałem, nie miałem na to czasu, czułem jednak, że to coś nie jest w porządku, skoro poszedłem potem do „Grażyny” i pytałem go, dlaczego to zrobili, na co ten odpowiedział, że jest to rozkaz odgórny. Będąc w oddziale, słyszałem coś o jakiejś akcji w lasach siekierzyńskich, lecz nie byłem tego świadkiem i nie mogę nic na ten temat powiedzieć.

\section{Własnoręczne oświadczenie Stanisława Różalskiego ${ }^{67}$}

Przy placówce organizacji AK w Ćmielowie istniała sekcja specjalna do wykonywania zadań. Kto był jej dowódcą, nie wiem, ale na akcje wysyłał Radomski ps. „Robak” i najczęściej mówił przy tym, że ja mam dowodzić tą grupą ludzi. Oficjalnie nie byłem powiadomiony że jestem dowódcą Sekcji Specjalnej. Dokładnie nie pamiętam, było to w roku 1943 lub 1944 gdzieś po żniwach, otrzymałem od Radomskiego ps. „Robak” rozkaz zlikwidowania Żydów, którzy ukrywali się we wsi Goździelin. Radomski podał mi kilka adresów, gdzie należało szukać ukrywających się Żydów, lecz obecnie tego nie pamiętam. Radomski nie mówił mi, ilu tych Żydów ukrywa się, lecz tylko gdzie oni się zbierają. Radomski dając mi polecenie zlikwidowania wspomnianych Żydów, oświadczył, że oni szkodzą nam. Radomski powiedział również, z kim mam udać się na tą [sic!] akcję, wymieniając po nazwiskach. Jak sobie przypominam, na akcję tą udał się wraz ze mną Nowacki, Cybula „Jastrząb” z Bodzechowa i jeszcze kilku, których obecnie nie pamiętam. Wykonując rozkaz Radomskiego, udaliśmy się do Goździelina. Byliśmy w jednym, następnie w drugim mieszkaniu, ale tam nie zastaliśmy Żydów. Nie pamiętam, czy była to Żydówka, czy Żyd. W mieszkaniu tym urządziliśmy zasadzkę i w chwilę później zaczęli schodzić się tam Żydzi. O ile sobie przypominam, przyszło wówczas siedem osób Żydów i Żydówek. Jeśli sobie przypominam, to wśród nich było trzech mężczyzn, dwie kobiety i dwoje dzieci. Wszyscy Żydzi zostali w tym mieszkaniu zastrzeleni. Oprócz mnie do wspomnianych Żydów strzelali Nowacki i Cybula. Dokonując zabójstwa wyżej wymienionych Żydów, nie zdawałem sobie sprawy z tego, co czynię. Miałem na uwadze wykonanie rozkazu. Wiedziałem, że rozkaz trzeba wykonać bezwzględnie. Obecnie zdaję sobie $\mathrm{z}$ tego sprawę, że postapiłem niehumanitarnie. Wiedziałem, że Żydzi są prześladowani przez Niemców. Dokonując zabójstwa Żydów, starałem się wykonać rozkaz. Od Żydów tych zabrane było trochę pieniędzy i trochę szmat. Za pieniądze urządziliśmy sobie kolację, a szmaty zostały u Jastrzębia w Bodzechowie - nie przedstawiały one większej wartości. W czasie tej akcji posiadałem pistolet „Vis”. Jak sobie przypominam,

${ }^{67}$ AIPN Ra, 29/138, Własnoręczne oświadczenie podpisane przez Stanisława Różalskiego, Kielce, 25 II 1959 r., k. 34-35. 
Nowacki miał parabellę, z której też strzelał do Żydów. Mówił później, że wypróbował sobie broń.

\section{Zeznanie Stanisława Różalskiego ${ }^{68}$}

Wyjaśniam, że w czasie okupacji należałem do organizacji AK na terenie Ćmielowa. Dowódcą mojego oddziału (kompanii) był Pękalski. Poza tym na terenie działania kompanii dowodzonej przez Pękalskiego działała sekcja specjalna dowodzona przez Radomskiego ps. „Robak”. Sekcja ta podlegała bezpośrednio pod dowództwo w Ostrowcu. Wyczuwałem, że Radomski nie pozostawał w stosunku zależności z Pękalskim. Ja członkiem sekcji specjalnej nie byłem, ale brano mnie dorywczo do poszczególnych akcji dokonywanych przez tą sekcję. Brano mnie do akcji dokonywanych przez sekcję specjalną na tej podstawie, że „zaprzysięgał mnie” (odebrał ode mnie przysięgę) poprzednik Radomskiego pseudonim „Kościesza”, którego nazwiska nie znam. W m-cu kwietniu 1943 r. otrzymałem od „Robaka” rozkaz zlikwidowania Żydów zamieszkałych w Goździelinie. [...] Poza tym w żadnych zabójstwach dokonywanych na tle politycznym lub rasowym udziału nie brałem. Również i ten rozkaz przyjąłem z niezadowoleniem. Niezadowolenie moje objawiałem w ten sposób, że powiedziałem Radomskiemu: ,jak rozkaz, to rozkaz, ale wolałbym nie jechać”. Radomski wydając mi polecenie, powiedział, żeby wszystkich od małego do dużego wystrzelać, tzn. zarówno dzieci, jak i dorosłych. Następnego dnia po wydaniu rozkazu Radomski przyszedł do mnie ponownie i wydał szczegółowe instrukcje, tj. wyznaczył miejsce zbiórki oraz jej czas, miejsce pobrania broni i czas akcji. Zbiórka miała nastąpić u mnie w Ćmielowie częściowo, a częściowo w Bodzechowie przy magazynie broni. Zgodnie z planem tego samego dnia zgłosili się u mnie Nowacki i Cybula, z którymi udałem się do Jastrzębia zamieszkałego w Bodzechowie. U Jastrzębia w mieszkaniu spotkałem się z pozostałymi uczestnikami akcji. Również od Jastrzębia została wzięta broń. Ja miałem „Visa”, nie pamiętam jednak, czy to była moja osobista broń, czy też ją wziąłem od Jastrzębia. Wszyscy pozostali również mieli broń krótką. U Jastrzębia pozostawiliśmy rowery i pieszo udaliśmy się do Goździelina. Szliśmy wszyscy razem. Na tym terenie, a między innymi na stacji w Bodzechowie stacjonowały wojska niemieckie, szliśmy jednak razem. Dodaję, że szliśmy polami. Z Bodzechowa wyszliśmy o szarówce, wkrótce byliśmy w Goździelinie, gdyż odległość Goździelina od Bodzechowa jest niewielka - wynosi około 2 km. [...] Radomski wskazał nam w Goździelinie 3 domy, w których mogą być Żydzi, od Jastrzębia wiedziałem dokładnie, w którym domu są Żydzi, toteż do 2 domów wszedłem sprawdzić tylko dla formalności. Wchodząc do tych domów, nic nie mówiłem, tylko patrzałem po twarzach znajdujących się tam ludzi, czy nie są podobni do Żydów. Do trzeciego domu, w którym byli Żydzi, weszło dwóch ludzi, którzy szli pierwsi. Po wyjściu z domu powiedzieli, że w mieszkaniu jest Żyd czy Żydówka. Poleciłem wówczas części ludziom pozostać w ukryciu

${ }^{68}$ AIPN Ra, 29/138, Protokół przesłuchania z 26 II 1959 r. przez prokuratora wojewódzkiego w Kielcach Leona Śliwińskiego, k. 34-36. 
koło domu, a sam z Nowackim i Cybulą wszedłem do mieszkania. W mieszkaniu zastałem istotnie jedną osobę narodowości żydowskiej. Nie pamiętam obecnie, czy był to mężczyzna, czy kobieta. Później do mieszkania tego przyszli następni Żydzi. Razem w mieszkaniu tym zeszło się 7 Żydów, w tym dwoje dzieci. Jedno dziecko w wieku około 6 lat, a drugie około 12. Wśród dorosłych byli zarówno mężczyźni, jak i kobiety. Dorosłych było 5, ile w tym mężczyzn, a ile kobiet, nie pamiętam. Zarówno osobę, którą zastaliśmy w mieszkaniu, jak i następne, które wchodziły do mieszkania, ustawialiśmy pod ścianą, twarzą do ściany. Prostuję, że nie ustawialiśmy ich $\mathrm{w}$ ten sposób, lecz poleciliśmy im tak się ustawić. W czasie gdy byli tak ustawieni, Nowacki zaczął szukać po ich rzeczach za pieniędzmi. Ile wziął pieniędzy, nie wiem. Pieniądze brał bez mojego polecenia. W tym czasie jak Nowacki zaczął szukać pieniędzy, jedna Żydówka posądziła nas, że jesteśmy bandytami, później powiedziała, że to jednak Polacy i nic złego nam nie zrobią. Na jej słowa nic nie zareagowaliśmy. Wkrótce potem zaczęliśmy strzelać. Pierwszy strzelił Cybula, następnie ja, Nowacki początkowo nie chciał strzelać, ale później powiedział, że wypróbuje sobie parabelkę i też strzelał. Ja osobiście zastrzeliłem 2 Żydów i 1 Żydówkę, ale nie pamiętam jednak dokładnie, czy tak było. Do dzieci strzelał Cybula i Nowacki. W czasie strzelania Żydzi na ogół zachowywali się spokojnie, krzyczała tylko 1 Żydówka i płakały dzieci. Gdzie strzelałem, nie pamiętam, zdaje się, że w plecy. Powalonych nie dobijaliśmy. Zaraz po strzałach wybiegliśmy stamtąd. Nowacki z Cybulą zabrali jeszcze przed wyjściem węzełki z odzieżą. Domu nie paliliśmy. Gdy byliśmy już w odległości koło $1 \mathrm{~km}$, zobaczyliśmy, że dom się pali. Przypuszczam, że podpaliła go właścicielka domu, w obawie by Niemcy nie znaleźli u niej zabitych Żydów. [...] Z Goździelina wróciliśmy do Jastrzębia w Bodzechowie. Nowacki wyjął po powrocie do Jastrzębia zabrane pieniądze i powiedział, że zjemy za nie kolację. Pieniądze wziął Jastrząb lub jego brat i przyniósł za nie 1/2 1 wódki oraz kiełbasy i chleba. Po zjedzeniu kolacji miejscowi uczestnicy udali się do swoich domów, a ja z Nowackim i Cybulą przenocowaliśmy u Jastrzębia, a rano na rowerach wróciliśmy do Ćmielowa. Dodaję, że wydając mi polecenie zastrzelenia Żydów, Radomski mówił, że trzeba ich zastrzelić, gdyż są szkodliwi dla naszej organizacji. Nie orientuję się, w jaki sposób ci Żydzi, a zwłaszcza małe dzieci mogły szkodzić naszej organizacji.

\section{Zeznanie Stanisława Tworka ${ }^{69}$}

Ja słyszałem, jak Różalski mówił, że pójdziemy do Czubiny do Goździelina zobaczyć, co się tam dzieje. Przed tym Mroczek zawiadomił Radomskiego ps. Robak, że do ob[ywatelki] Czubiny zam. w Goździelinie schodzą się nieznani ludzie, którzy przynoszą ze sobą pakunki. Mroczek w mej obecności pisał meldunek na ten temat, który następnie wysłał do Robaka. Ja meldunek ten czytałem. Nie było jednak w nim napisane, że do Czubiny przychodzą Żydzi. Mroczek nadmienił w meldun-

${ }^{69}$ AIPN Ra, 29/138, Protokół przesłuchania z 6 III 1959 r. przez prokuratora wojewódzkiego w Kielcach L. Śliwińskiego, k. 59. 
ku, iż należałoby sprawdzić, co to za ludzie przychodzą do Czubiny, więc idąc na wspomnianą akcję, byłem przekonany, że idziemy w celu sprawdzenia, co za ludzie przychodzą do Czubiny. [...] Miałem obserwować drogę u wylotu wsi Goździelin. [...] Mroczek niósł dwa pakunki, jak się później okazało, była to bielizna zamordowanych Żydów. Udaliśmy się do Mroczka, gdzie Różalski obejrzał przyniesioną bieliznę. Ponieważ nie przedstawiała ona większej wartości, więc Różalski kazał ją zakopać Mroczkowi. Bielizna ta została zakopana przez Mroczka za jego stodołą. Jak się zorientowałem, zamordowanym Żydom zabrane zostały również pieniądze. Pieniądze miał Różalski, w sumie około 200 zł (dwieście). [...] Wśród zabranych szmat była opaska noszona przez Żydów w gettach. Wydaje mi się, że w domu u Mroczka Różalski przeglądał jakieś świstki zabrane pomordowanym. W czasie ich przeglądania Różalski mówił, że zastrzelonymi są Żydzi. W mieszkaniu u Mroczka Różalski czyścił sobie zaplamione krwią spodnie.

\section{Wyrok}

13. Sentencja wyroku Sądu Wojewódzkiego w Kielcach ${ }^{70}$

Stanisława Różalskiego uznaje za winnego dokonania zarzucanego mu aktem oskarżenia przestępstwa i [...] skazuje go na 7 (siedem) lat więzienia [...] oraz pozbawienia go praw publicznych i obywatelskich praw honorowych na okres trzech lat. Zasądza od niego 800 zł opłaty sądowej oraz obciąża kosztami postępowania.

\section{Uzasadnienie wyroku Sądu Wojewódzkiego w Kielcach ${ }^{71}$}

Co do Żydów ukrywających się w Goździelinie, to fakt ten był znany dowództwu AK, gdyż jak podaje świadek Tworek, komendant placówki AK w Bodzechowie, Mroczek składał odnośny meldunek. Gdyby miejscowi członkowie organizacji mieli na celu dokonanie rabunku, to na pewno nie meldowaliby o Żydach swoim władzom. Nie mógł tego zrobić na własną rękę i oskarżony. Zresztą samo dokonanie zabójstwa w formie jawnej i oficjalnej akcji wyklucza jakiekolwiek działanie na własną rękę. O takiej akcji władze musiały dowiedzieć się i winni ponieśliby surową odpowiedzialność. Wbrew zeznaniom świadka Radomskiego nie można wprost uwierzyć, aby nie wiedział on o akcji w Goździelinie, bo przecież ze względu na dużą ilość zabitych, pożar, przybycie Niemców itd. głośno było o niej w całej okolicy, a przecież Radomski był szefem wywiadu podrejonu, na którego terenie akcja miała miejsce. Zresztą tenże Radomski osobiście angażował do akcji świadka Cybulę. Te wszystkie okoliczności zdaniem Sądu przemawiają wyraźnie, iż oskarżony Różalski mówi prawdę i że działał na skutek otrzymanego od Radomskiego rozkazu. Niewątpliwie władze AK opierając się na meldunkach Mroczka, wydały rozkaz likwidacji Żydów jako trudniących się rabunkami. Tego rodzaju rozkazy nakazujące likwidację Żydów na terenie okręgu kieleckiego powtarzały się bardzo

${ }^{70}$ AIPN Ra, 29/138, Sentencja wyroku Sądu Wojewódzkiego w Kielcach z 25 III 1960 r., sędzia orzekający T. Bielski, k. 152.

${ }^{71}$ Ibidem, k. 157-159. 
często w szeregu rozpoznawanych spraw. [...] Co do ograbienia Żydów, to należy dać wiarę oskarżonemu, że zrobił to na własną rękę świadek Nowacki, który w czasie akcji był silnie pijany. Sam oskarżony, jako właściciel sklepu, nie był biedny i nie łaszczyłby się na mało wartościową garderobę. Zresztą nikt ze świadków nie stwierdził, aby Żydów przed zastrzeleniem rewidowano, a na drugi dzień dzieci znalazły poopalane banknoty dolarowe. Ta okoliczność wyraźnie wskazuje, że nie chodziło o mienie żydowskie. Zabraną przez Nowackiego garderobę użyto do czyszczenia broni, a gotówkę przeznaczono na wódkę. [...] Działanie pod wpływem rozkazu nie zwalnia oskarżonego od odpowiedzialności, a stanowi jedynie okoliczność łagodzącą. Zresztą oskarżony był na stanowisku kierowniczym i rozkazu mógł nie wykonać, gdy zorientował się, że chodzi o kobiety i małe dzieci żydowskie, nie mogące być poza Niemcami dla nikogo niebezpieczne i szkodliwe.

\section{Zabójstwo członka AK „Misia”, las koło Lisowa, czerwiec 1944 r.}

\section{Świadkowie}

1. Zeznanie Bolesława Kołbuca na rozprawie głównej ${ }^{72}$

W r. 1944 pełniłem służbę wraz z ojcem, któremu pomagałem w gajówce koło wsi Lisów. Obchodząc pewnego dnia rano las, znaleźliśmy krew i świeżo wykopany grób. [...] Krew była tuż obok mogiły. Zainteresowaliśmy się tym. Udaliśmy się na skraj lasu i w stronę Lisowa i spotykając ludzi, pytaliśmy, co słychać we wsi. Ludzie powiedzieli, że była we wsi grupa Zawiszy, która miała zastrzelić jakiegoś Żyda, doktora będącego członkiem tej grupy. Mówili o tym: Jan Kasiński, Mikołaj Kasiński, Józef Rzetelny, Jan Grad i Maria Borkowska. To była sprawa głośna we wsi. Mówili, że wieziono tego lekarza początkowo w pole, ale ludność się kręciła - więc udano się do lasu. Nikt ze wsi nie był wynajęty na furmana. Nikt nie szedł do lasu, by zobaczyć, co się stanie. Ja zaznaczyłem miejsce, gdzie była mogiłka, ale działania wojenne (kopano w tym lesie rowy strzeleckie) tak zmieniły teren, że w 1949 r., gdy UB z Ostrowca prowadziła poszukiwania przy naszym udziale - to nic już nie znaleźliśmy. Krew była także i na liściach krzewów rosnących obok mogiłki na wysokości 1 metra (las był liściasty). Śladów kul nie widziałem. Ślady spotkaliśmy o godz. 7 rano i z ludźmi rozmawialiśmy nieco później o 8-ej lub 9-ej godzinie. Ludzie mówili, że tego doktora wieziono poprzedniego dnia przed wieczorem. Na mogiłkę trafiliśmy przypadkowo, była zamaskowana liśćmi, krew była częściowo zeskrobana. Należałem do BCh.

\section{Zeznanie Bolesława Kołbuca na rozprawie głównej ${ }^{73}$}

Słyszałem od gospodarzy wsi, a mian[owicie] od Jana Kosińskiego [właśc. Kasińskiego], od Mikołaja Kosińskiego [właśc. Kasińskiego], Jana Gradka [właśc.

${ }^{72}$ AIPN Ki, 126/117 (dawna sygn. GK, 217/117), Protokół rozprawy głównej przez Sądem Apelacyjnym w Kielcach w dniu 13 II 1950 r., k. 59-60.

${ }^{73}$ AIPN, GK, 217/45, Protokół rozprawy głównej przed Sądem Apelacyjnym w Kielcach w dniach 21-23 II 1950 r., k. 101. 
Grada] i Bordowskiego, że oddział Zawiszy miał sąd przy drzwiach zamkniętych i że tam rozstrzygano sprawę, co zrobić z tym lekarzem. Tam też wydano na niego wyrok śmierci, choć on podobno bardzo prosił, aby mu nie odbierano życia. Ale Zawisza twardo stał na swoim stanowisku. Potem wywieźli furmanką tego Żyda i po drodze on im jeszcze podobno uciekał, rozkaz jednak wykonano. Wieźli go ludzie z oddziału Zawiszy, którzy, tego nie wiem. Zawisza wtedy kwaterował w okolicy. [...] Wszyscy ludzie we wsi byli ciekawi i chodzili oglądać tę mogiłę. [...] Żyd ten był podobno przed tym badany na kwaterze u Łukasińskiego [tak w tekście, powinno być: u Kasińskiego - J.M., A.S.].

\section{Oskarżeni}

\section{Zeznanie Władysława Kolasy ${ }^{74}$}

Będąc w oddziale „Zawiszy”, w m-cu maju 1944 r. (w końcu) oddział nasz kwaterował w Lisowie pow. Opatów i wówczas z rozkazu „Zawiszy” został zabity ppor. doktor „Miś”, który był doktorem w naszym oddziale, jako członek AK. Zabity został pod zarzutem, że jest narodowości żydowskiej, jak również zarzucono mu, że po zaszczepieniu czł[onka] oddziału p-ko tyfusowi kilkunastu z nich chorowało na wskutek opuchlizny. Zaznaczam, że mimo tej choroby żaden ze szczepionych nie umarł. Nadmieniam, że przed zabiciem dr. „Misia” tego samego dnia - przez kom[endanta] Obwodu AK był przysłany do naszego oddziału doktór ze Smiłowa pow. Opatów z poleceniem stwierdzenia, czy dr „Miś” jest faktycznie pochodzenia żydowskiego. Co też dr ze Śmiłowa (którego w ogóle nie znam) uczynił, stwierdzając, że dr „Miś” jest faktycznie Żydem. Wyrok śmierci na dr. „Misia” został wykonany w lesie lisowskim z rozkazu d-cy oddziału AK „Zawiszy” przez czterech lub pięciu członków tegoż oddziału, tj. Śledzia Jana ps. „Jelenia”, „Bystrego”, „Osa” (dalszych dwóch dokładnie nie pamiętam) gdyż w czasie tego morderstwa nie byłem obecny w oddziale (wyjechałem służbowo), a fakt powyższy znany mi jest z opowiadania „Jelenia”.

\section{Zeznanie Władysława Kolasy ${ }^{75}$}

Początkowo „Zawisza” po wezwaniu jakiegoś lekarza ze Śmiłowa, który stwierdził, że dr „Miś” jest Żydem, chciał, by się sam zastrzelił, zostawiając mu w tym celu pistolet i jedną szt[ukę] amunicji, ponieważ dr „Miś” odmówił, przeto polecił go wyprowadzić do lasu i rozstrzelać, co też i uczyniono, w drodze do lasu spotkano rządcę majątku Lisów i do niego zwrócił się dr „Miś”, by powiadomił „Topora” o tym, że „Zawisza” kazał go rozstrzelać.

${ }^{74}$ AIPN, GK, 411/216, Protokół przesłuchania z 4 III 1949 r. w WUBP w Kielcach, starszy referent Ryszard Kuźdub, k. 112.

${ }^{75}$ Ibidem, Protokół przesłuchania z 30 III 1949 r. w WUBP w Kielcach, oficer śledczy Stefan Barański, k. 122. 


\section{Zeznanie Edwarda Sternika ${ }^{76}$}

[...] był w naszym oddziale doktor lekarz ps. „Miś”, który jednak nie wykazywał, by był rzeczywistym lekarzem. W oddziale poczęły krążyć pogłoski, że jest on nie lekarzem, a szpiegiem niemieckim. Ponieważ wśród ludzi szerzyła się choroba świerzbu, a „Miś” nie mógł ludzi wyleczyć, d-ca „Zawisza” sprowadził lekarza i wszyscy zostaliśmy poddani badaniu. Po badaniu „Zawisza” wezwał mnie i rozkazał mi udać się z żołnierzami, gdzie, nie mówił, tylko powiedział mi, że żołnierze wiedzą, gdzie mamy się udać i co zrobić. W tym czasie już stał wóz, na którym siedział rozbrojony „Miś” i paru żołnierzy. Siadłem na ten wóz i ja i pojechaliśmy do lasu. [...] Dodaję, że „Miš” przebywał w oddziale około 1 miesiąca i nawet się z nim zżyłem. Czy był on Żydem, nie wiem, a strzelając, sądziłem, że strzelam do szpiega, którego ujawniło dowództwo. Wszystkie te czynności wykonywałem tylko z rozkazu i w obawie przed odpowiedzialnością za niewykonanie rozkazu, za co czekała śmierć. W strzelaniu grupy ludności żydowskiej osobiście nie brałem udziału i na to nie mogłem patrzeć, odwracając się w innym kierunku. Wypadku tego nie mogę do dziś zapomnieć. Z „Zawiszą” byłem w złych stosunkach. Słyszałem, że „Zawisza” więcej wydał takich rozkazów.

\section{Zeznanie Edwarda Sternika ${ }^{77}$}

Badanie „Misia” odbyło się na kwaterze „Zawiszy” w obecności mnie i por. „Roga”, zastępcy „Zawiszy”. Następnie wezwał mnie powtórnie do siebie „Zawisza” i powiedział, że na „Misia” zostanie wykonany wyrok śmierci. Ludzi do tego celu wyznaczył osobiście i „Miś” siedział już na wozie rozbrojony, którego pilnowali Śledź ps. „Jeleń”, „Toporek”, „Wyrwa” i „Bystry”. Zgodnie z rozkazem „Zawiszy” udałem się furmanką wraz z ww. do lasu za wsią Lisów, gdzie wtedy kwaterowaliśmy. Jadąc drogą, „Miś” wiedział, że jedziemy go rozstrzelać i z tego powodu usiłował uciekać, lecz był łapany, a kiedy podjechaliśmy pod las za Lisowem, „Miś” wyskoczył z wozu i zaczął uciekać, a wtedy ja pierwszy strzeliłem do niego z posiadanego pistoletu marki „Schmidt” i w tym momencie zaczęli strzelać i pozostali - w wyniku czego „Miś” został zastrzelony, a następnie przeniesiony w głąb lasu i pochowany (zakopany). Odnośnie [do] „Misia” „Zawisza” powiedział mi, że jest to szpieg niemiecki, natomiast jak słyszałem od żołnierzy z oddziału, „Zawisza” mówił im, że „Miś” odjechał na melinę. Przypuszczam jednak, że ludzie wiedzieli, jak sprawa ta jednak przedstawia się w rzeczywistości.

${ }^{76}$ Ibidem, Protokół przesłuchania z 10 III 1949 r., prokurator Sądu Okręgowego w Kielcach Władysława Haśkiewiczowa, k. 153.

${ }^{77}$ Ibidem, Protokół przesłuchania z 8 VI 1949 r. w WUBP w Kielcach, oficer śledczy Marian Duda, k. 171. 


\section{Zeznanie Edwarda Sternika na rozprawie głównej ${ }^{78}$}

Lekarz ten nie wywiązywał się ze swoich obowiązków lekarskich i sam to widziałem i doniosłem. Np. po podaniu lekarstwa na żołądek stan zdrowia pogorszył się. „Zawisza” zwrócił mi uwagę, aby z „Misiem” nie rozmawiać za dużo w sprawach organizacji, gdyż „Miś” jest podejrzany, że pracuje dla wywiadu niemieckiego. Nie wiem, jakiej narodowości był „Miś”, do Żyda nie był podobny. W czerwcu 1944 r., gdy stan zdrowotny oddziału pogarszał się bardzo widocznie (cały oddział był zaświerzbiony), mimo że „Miś” leczył - przybył do nas inny lekarz i stwierdził, że stan zdrowia oddziału jest niezadowalający. Po pewnym czasie - byliśmy wtedy w Lisowie - „Zawisza” wezwał mnie do swej kwatery i oświadczył, że „Miś” zostanie przekazany do kwatery obwodu AK i że odwiezie go grupa żołnierzy. Mnie polecił, bym, jako oficer, pojechał do asysty, gdyż „Miś” też był oficerem. Misia zastałem już rozbrojonego. Wsadzono go na przygotowany wóz, zaprzężony w parę koni. Droga i miejsce dostarczenia nie były mi znane. W czasie drogi „Miś” zaczął zdradzać pewne obawy i zaczął się rzucać i zeskakiwać z wozu - żołnierze trzymali go. Jeszcze uprzednio „Miś” był ostrzegany, tzn. ja go ostrzegałem na wozie, gdy wsiadaliśmy, by nie starał się uciekać, bo narazi się na to, że zostanie użyta broń. Nie przypominam sobie, czy go ostrzegłem z własnej inicjatywy, czy na rozkaz dowódcy. Nie wiem, kto był dowódcą grupy wiozącej „Misia” i kto otrzymał rozkaz jazdy. Nie pamiętam, kto kierował drogą. Było nas oprócz „Misia”: ja, sierżant Śledź, oskarżony [Henryk Wierzbiński], plutonowy „Bystry” i kapral „Wyrwa”. Ilu jechało - nie pamiętam. Jechaliśmy nieznaną mi drogą, naprzód wsią, potem polem do lasu. W pewnym momencie, gdy byliśmy już blisko lasu, „Miś” zeskoczył z wozu i począł uciekać. Ja widząc, że może uciec, oddałem w jego kierunku strzał z pistoletu „Smith”. Zaraz potem usłyszałem serię z broni automatycznej. Kto ją oddał - nie widziałem. Rozkazu do strzelania nie było. Jak „Miś” zeskoczył, to i wszyscy żołnierze zeskoczyli z wozu za nim. Chwycił go Śledź, lecz „Miś” wyrwał się i uciekał dalej. Ja krzyknąłem: stój, i oddałem strzał ostrzegawczy, ale w zdenerwowaniu nie zwracałem [uwagi] na kierunek strzału. „Miś” uciekał w stronę pola. W którym momencie upadł, nie zauważyłem. Gdy ja dawałem strzał, byłem o 30 m od „Misia”. Seria poszła z mojej lewej strony i strzelający był ode mnie o jakie $50 \mathrm{~m}$ w lewo, w krzakach. Nie pamiętam, czy było jedno źródło ognia, może dwa. „Miś” miał po kilka strzałów w głowę i w tułów. Po stwierdzeniu, że nie żyje, kilku poszło po łopaty do sąsiednich domów - pochowaliśmy „Misia” w lesie ok. 50 m od drogi, a ok. 100 m od lasu. Znaku żadnego nie zostawialiśmy. Nie pamiętam, czy zasypaliśmy mogiłę liśćmi. [...] Byłem jako asysta z polecenia „Zawiszy”. Uważałem się za konwojenta i użyłem broni, bo przewiduje to regulamin. Misia uważałem na podstawie własnych obserwacji za szpicla. „Miś” obniżał wartość bojową żołnierzy przez stosowanie złych leków. Zajście było po południu ok. g[odziny] 16. Nie pamiętam, kto wydał rozkaz pogrzebania.

${ }^{78}$ AIPN Ki, 126/117, Protokół rozprawy głównej przed Sądem Apelacyjnym w Kielcach w dniu 13 II 1950 r., k. 60 (Sternik zeznawał jako świadek w sprawie karnej Henryka Wierzbińskiego). 
8. Zeznanie Jana Górskiego na rozprawie głównej ${ }^{79}$

„Miś” jeździł często na parę dni rzekomo po opatrunki do Kalisza. Ponieważ dosyć długo często nie wracał i w ogóle w jego zachowaniu było coś niewyraźnego, zwróciliśmy na to uwagę „Zawiszy”. Co było dalej, nie wiem.

\section{Zeznanie Henryka Wierzbińskiego ${ }^{80}$}

[...] zostałem wezwany przez „Zawiszę”, który oznajmił mi, ażebym wsiadał na wóz i jechał razem z ppr. „Grzegorzem”. Nadmieniam, że na wozie tym siedział już ppr. „Miś”, doktor oddziału AK, ubrany w mundurze wojskowym, lecz bez broni palnej, a przy nim siedzieli ppr. „Grzegorz”, „Bystry”, „Jeleń” i „Grześ”, do których ja dosiadłem. [...] Następnie „Grzegorz” powiedział, że jedziemy do dowództwa obwodu, lecz gdzie i jakiego - tego nie mówił. Podczas jazdy dr „Miś” próbował uciekać, lecz został ujęty przez „Grzegorza” i ponownie posadzony na furmankę. W międzyczasie przejeżdżając obok majątku za wsią Lisów, dr „Miś” spotkał swego znajomego kolegę z tegoż majątku, mnie osobiście nieznanego, do którego dr „Miś” powiedział: „powiedzcie (komu, nie pamiętam), że ja będę przez Zawiszę rozstrzelany”. Gdy furmanką tą zbliżyliśmy się w stronę lasu drogą polną od wsi Lisów w odległości około 1-go km, dr „Miś” ponownie usiłował nam zbiec z furmanki i gdy zeskoczył z fury i oddalił się około 7-miu metrów, ppr. „Grzegorz” dał rozkaz strzelać i on pierwszy strzelił w kierunku uciekającego dr „Misia” z rewolweru syst[emu] „Schmitch” bębenkowego. Jednocześnie ja oddałem serię z posiadanego automatu syst[emu] „Sten”, na skutek czego dr „Miś” upadł na ziemię nieżywy. Po dojściu do leżących zwłok dr. „Misia” stwierdziliśmy, że został on trafiony jedną kulą w serce, prawdopodobnie z rewolweru syst[emu] „Schmitch” przez „Grzegorza”, oraz czterema pociskami z automatu syst[emu] „Sten”, tj. k[a]l[i]b[er] $9 \mathrm{~mm}$ po lewym ramieniu i głowie trafionymi przeze mnie. W tym czasie już dr „Miś” żadnych znaków nie dawał. Z oświadczenia ppr. „Grzegorza” wynika, że jego strzał był śmiertelny, który wyraził się tymi słowy: „ale trafnie strzeliłem w samo serce”. Niemniej moje strzały były trafne i śmiertelne [...]. Po dokonanym zabójstwie zwłoki dr. „Misia” zostały obnażone z odzieży, tj. munduru wojskowego, spodni i butów z cholewami w dobrym stanie przez Śledzia ps. „Jeleń” i „Grzesia”, po czym wspólnie zwłoki te zakopaliśmy. [...] Widziałem po tym, że w butach po zabitym dr. „Misiu” chodził Śledź Jan ps. „Jeleń”, a w mundurze i spodniach chodził Różalski Jerzy ps. „Sarna”. Nadmieniam, że ja nie otrzymałem żadnego rozkazu od por. „Zawiszy” celem zlikwidowania dr. „Misia”, a d-cą eskorty był ppr. „Grzegorz” i on widocznie taki rozkaz otrzymał, czego stwierdzić konkretnie nie mogę. Ja tylko byłem jako konwojent wyznaczony przez „Zawiszę” do pomocy „Grzegorzowi”, co też uczyniłem. [...] Zauważyłem, że [„Miś”] jako człowiek był bardzo przyzwoity,

${ }^{79}$ AIPN, GK, 217/45, Protokół rozprawy głównej przed Sądem Apelacyjnym w Kielcach w dniach 21-23 II 1950 r., k. 91.

${ }^{80}$ AIPN Ki, 126/117, Protokół przesłuchania z 5 XII 1949 r. w Powiatowym Urzędzie Bezpieczeństwa Publicznego w Ostrowcu, starszy oficer Jan Walaszczyk, k. 27-29. 
koleżeński, spokojny i żadnej większej działalności w ramach tejże organizacji nie przejawiał, leczył chorych członków organizacji, lecz nie wiem, czy był on faktycznie lekarzem, czy nie, ponieważ były narzekania na niego przez członków, których leczył, że źle leczy. Czy faktycznie był on Żydem, tego nie wiem, gdyż ja osobiście nie stwierdziłem. Dodaję, że w czasie dokonywania zbrodni zostały odebrane dowody osobiste dr. „Misiowi”, którego jak sobie przypominam nazwisko brzmiało: Jaśkowicz, imienia nie pamiętam. Dowody te zabrał ppr. „Grzegorz”, lecz co z nimi zrobił, tego nie wiem.

\section{Zeznanie Henryka Wierzbińskiego na rozprawie głównej ${ }^{81}$}

Rozmawiałem potem na ten temat z oskarżonym Śledziem i powiedziałem, że szkoda chłopa, na co mi Śledź odpowiedział, że jeśli go żałuje [sic!] to po cóż do niego strzelałem. Wiem, że wszyscy w oddziale narzekali na „Misia”, że źle ich leczył, była taka opinia ogólna, że był on szpiegiem niemieckim i dlatego źle leczył. Mówiono, że jest coś podejrzanego u niego, bo stale jeździ do miasta, ma jakieś dziwne kontakty, no i źle leczy. To wszystko składało się na ujemną o nim opinię. [...] W oddziale jednak pytano o niego, choćby dlatego, że widziano jego mundur i buty. Po „Misiu” jego następcą był lekarz „Lepszy”82, Żyd, który był zresztą bardzo do Żyda podobny i w oddziale wyraźnie mówiono o jego pochodzeniu. Pozatem był jeszcze Żyd Olsza ${ }^{83}$, który również był podobny do Żyda. Nie mieli oni w oddziale żadnych przykrości z tego tytułu. [...] Nie wiem, czy oprócz mnie i „Grzegorza” strzelał jeszcze ktoś do „Misia”.

\section{Zbrodnia w lesie siekierzyńskim, sierpień 1944 r.}

\section{Protokół oględzin miejsca przestępstwa ${ }^{84}$}

W toku prowadzonych oględzin ustalono, że w lesie siekierzyńskim, gm. Bodzentyn, w odległości 4 km (cztery) od wsi Kaczka gm. Wąchock, na łące znajduje się kopiec z palem granicznym oddzielającym łąki włościańskie wsi Siekierno od

${ }^{81}$ AIPN GK, 217/45, Protokół rozprawy głównej przed Sądem Apelacyjnym w Kielcach w dniach 21-23 II 1950 r., k. 90

82 „Lepszy” - Żyd, miał być w oddziale Zawiszy po „Misiu” do jesieni 1944 r., Wojciech Borzobohaty podaje, że dr "Lepszy” to podporucznik Adam Brower-Paszkowski, lekarz 1. baonu 4. pp Leg. AK. Antoni Sułowski na podstawie relacji Jana Pękalskiego napisał, że „po wyzwoleniu kraju dr «Lepszy» pod nazwiskiem Paszkowski pracował w Pruszkowie, zyskując uznanie pacjentów. W 1958 roku okazało się, że nie ukończył studiów medycznych i nie przysługuje mu stopień doktora, za co pociągnięto go do odpowiedzialności. Ukończył jednak potem studia i nadal pracował jako lekarz" (Sułowski, U podnóża Gór Świętokrzyskich..., s. 81).

${ }^{83}$ „Olsza” - podchorąży w oddziale „Zawiszy”, miał być Żydem. Był w oddziale do demobilizacji w listopadzie $1944 \mathrm{r}$.

${ }^{84}$ AIPN, GK, 411/216, Protokół oględzin miejsca przestępstwa podpisany przez oficera śledczego WUBP w Kielcach Mariana Dudę, Kaczka, 13 VIII 1949 r., k. 83 (na kolejnej karcie znajduje się szkic sytuacyjny miejsca przestępstwa). 
lasu państwowego oddz. 57 leśnictwa Kaczka - nadleśnictwa Siekierno. Jak wynika z zeznań świadków będących przy zakopywaniu pomordowanych i obecnych przy dzisiejszych oględzinach, morderstwo dokonane zostało na przestrzeni od kopca granicznego do stojących w łące samotnie dwóch olch, co równa się w linii prostej 19 m (dziewiętnaście) w kierunku północno-wschodnim. Po dokonaniu morderstwa i obnażeniu zwłok z odzieży trupy te zostały złożone na stos w lesie, w odległości 49 m (czterdziestu dziewięciu) w linii prostej od pola granicznego w kierunku północno-zachodnim, a następnie przeniesione i zakopane w odległości $28 \mathrm{~m}$ (dwadzieścia osiem) metrów od pola granicznego w kierunku północnym. Sama mogiła, w której jak wynika z oświadczenia świadków, znajduje się około 50 (pięćdziesiąt) obnażonych z ubrań trupów, jest równa z pozostałym terenem, tylko nieco wklęsła ku środkowi, tak że wyraźnie zarysowują się brzegi. Powierzchnia mogiły o długości $10 \mathrm{~m}$ (dziesięć) i szerokości $2 \mathrm{~m}$ (dwa) jest porosła bujnym sitowiem i innymi chwastami. W odległości $5 \mathrm{~m}$ (pięć) od mogiły rośnie dzika stara jabłoń, które to drzewo rzadko spotyka się w lesie. Jak stwierdzają świadkowie, trupy pomordowanych w mogile ułożone zostały w poprzek i do chwili obecnej tam się znajdują, co jednocześnie potwierdza wydobywająca się w czasie kłucia ziemi woń.

\section{Świadkowie}

2. Zeznanie Stanisława Szumielewicza ${ }^{85}$

W lipcu czy sierpniu 1944 r., daty bliżej nie pamiętam, jednego dnia słyszałem w lesie za wsią strzały z broni maszynowej, a we wsi mówiono, że kogoś rozstrzeliwują. Drugiego dnia pognałem tam, tj. w miejsce, gdzie poprzedniego dnia strzały te słychać było, gdzie po dłuższym poszukiwaniu po lesie, wspólnie z Szumielewiczem Władysławem, Arendem Czesławem i Ślęzakiem Henrykiem, wszyscy ze wsi Stawek Stary, znaleźliśmy stos trupów liczący około 40-50 osób. Trupy te były porozbierane z ubrań i leżały nago. Stos ten na wierzchu nakryty był gałęziami i stał na skraju lasu koło łąki leśnej w lesie siekierzyńskim w oddaleniu do 3-ch km od wsi Kaczka. Po podejściu bliżej do leżących w stosie trupów zauważyłem, że między mężczyznami znajdowały się tam i kobiety. Na ciele trupów, szczególnie na głowach i piersiach, znać było ślady strzałów i całe ciała trupów tych były zakrwawione. $\mathrm{W}$ tym czasie kiedy myśmy tam byli, palił się jeszcze ogień, a właściwie był jeszcze w popiele - z ubrań tych trupów, co zrozumieliśmy po rozrzuconych wkoło szmatach. Trzeciego dnia po rozstrzelaniu trupy te zostały z polecenia partyzantów polskich zakopane w lesie, w tym miejscu, gdzie leżały na stosie. Pamiętam jeszcze, że kiedy przygnałem krowy z pastwiska partyzanci opowiadali [do] ludzi, aby szli tych trupów zakopać. [...] Jak słyszałem z opowiadania ludzi, pomordowanymi osobnikami mieli być Żydzi ze Skarżyska, którzy uciekli z tamtejszych zakładów zbrojeniowych, tzw. „Hasagu” [por. przyp. 35] i ukrywali się przed Niemcami w lesie koło wsi Kaczka.

${ }^{85}$ AIPN, GK, 411/216, Protokół przesłuchania z 17 I 1949 r. w WUBP w Kielcach, oficer śledczy Marian Duda, k. 71-72. 


\section{Zeznanie Władysława Młynarczyka ${ }^{86}$}

[...] kiedy byłem w domu, przyszło do mnie dwóch partyzantów polskich z bronią, ubranych w mundury Wojska Polskiego i polecili mi zabrać z sobą łopatę oraz z nimi udać się do lasu. Jak zorientowałem się w dalszej drodze do pracy tej zabrali oni jeszcze Malinowskiego Stefana, Szumielewicza Stanisława i Babiarza Mieczysława oraz kilku innych ludzi. Na miejscu rzekomej pracy prowadziło nas pięciu partyzantów. Partyzanci ci zaprowadzili nas w las siekierzyński, w odległości około 5 km od wsi Kaczka, gdzie polecono nam wykopać dół - jak sobie obecnie przypominam, około $3 \mathrm{~m}$ szeroki, 3,5 m długi i około 70-85 cm głęboki. Po wykopaniu tego dołu pokazano nam dopiero leżący około 20 m od miejsca wykopu stos trupów ludzkich, które były obnażone z ubrań, ułożone w stos w krzakach obok łąki leśnej i trupy te polecono nam zakopać w uprzednio wykopanym dole. Ile trupów tych było, obecnie nie pamiętam, z powodu że ich nie liczyłem, lecz ilość ich mogła być 40-50 osób. [...] Ogólny widok terenu morderstwa na wspomnianej łące był wstrząsający, na które mógł sobie pozwolić tylko okupant. Jakieś sto metrów kwadratowych na łące zalane było zsiadłą krwią, na której żerowało mnóstwo much, a obok łąki w krzakach stos trupów ludzkich. Jak zorientowałem się z całokształtu sprawy, część odzieży pomordowanych została spalona na miejscu, o czym świadczyły ślady ogniska na łące i leżące obok niedopalone szmaty. Natomiast jak mi jest wiadomo z opowiadania Stypuły Jana z Mostek, który obecnie pracuje gdzieś w fabryce w Kielcach, w tym czasie został mu zabrany wóz z koniem, którym mordercy przewozili z lasu lepszą garderobę i wóz ten z koniem Stypule nie został oddany. Na trupach pomordowanych były ślady strzałów seryjnych po całym ciele oraz ślady uderzeń, co świadczyło że byli oni dobijani. [...] Z polecenia partyzantów trupy te zostały przez nas z [a] ciągnięte do wykopanego dołu i zasypane równo bez żadnego wzniesienia. Przed zwolnieniem nas od tej pracy stojący nad nami partyzanci zapowiedzieli nam, aby nikomu o tym nie mówić, bo w przeciwnym razie czeka nas kula w łeb.

\section{Oskarżeni}

4. Zeznanie Władysława Kolasy ${ }^{87}$

W czasie kiedy kwaterowaliśmy w Siekiernie, zgłosiło się na placówkę czterech młodych Żydów za poszukiwaniem żywności. Wymienieni Żydzi zostali zatrzymani i dostawieni do dowódcy oddziału por. „Zawiszy”, ten w rozmowie z nimi dowiedział się, że jest ich duża grupa w lasach Siekierzeńskich. Tu nie wiem dokładnie, czy por. „Zawisza” w porozumieniu i z rozkazu pułk. „Kruka” Żydów wymordował, czy też z własnej inicjatywy dał rozkaz. Na wezwanie d-cy oddziału „Zawiszy” melduje się por. „Grzegorz”, d-ca plutonu oddziału „Zawiszy”, i por. „Zygmunt”, d-ca

${ }^{86}$ AIPN, GK, 411/216, Protokół przesłuchania z 17 I 1949 r. w WUBP w Kielcach, oficer śledczy Marian Duda, k. 73-74.

${ }^{87}$ Ibidem, Protokół przesłuchania z 24 I 1949 r. w WUBP w Kielcach, oficer śledczy Leon Barański, k. 93-94. 
plutonu oddziału „Zawiszy”. Jakie dostają wytyczne w tym kierunku, żołnierze nie wiedzieli. Po zebraniu plutonów przez wymienionych oficerów oddziału „Zawiszy” w szyku luźnym oddziały doszły w głąb lasu siekierzyńskiego na czele których prowadzili Żydzi. Na miejscu w lesie oddziały zastały kwaterujących tam Żydów obojga płci, gdzie było około 50-ciu mężczyzn i 6-8-miu kobiet, w tym dwie dziewczynki. Przez Żydów co zostaliśmy doprowadzeni [tak w tekście - J.M., A.S.] zostali wezwani pozostali w lesie i dwójkami zostali wyprowadzeni na polanę, gdzie miał się odbyć rzekomy spis, który miał był wykonany przez sierżanta „Boleroka”. „Bolerok” w porozumieniu z por. „Grzegorzem” i por. „Zygmuntem” dobrali ludzi z obydwóch plutonów z automatami i ustawił ich w odległości od czterech do pięciu metrów za tyłem do nich stojącymi Żydami. Na umówiony znak przy podniesieniu ręki przez „Boleroka” padła seria z automatów, gdzie po chwili był wykonany mord. Ludzi w pluton egzekucyjny wchodziło około 20-ścia osób wyznaczonych przez sierżanta „Boleroka”. Ludzi tych nie znam, iż była to zbieranina i świeżo przybyli do oddziału zdemobilizowani.

W czasie kiedy miała nastąpić egzekucja por. „Grzegorz”, mówiąc słowami do czł[onków] oddziału że kto nie może znosić takich rzeczy, może odejść na bok. Po tych słowach sam „Grzegorz” por. „Zygmunt” i kilku podoficerów między którymi byłem i ja ps. „Leń” jako podoficer w stopniu plutonowego i kilku żołnierzy ze wszystkich drużyn odeszliśmy na bok. Egzekucja była wykonana w momencie, że nawet Żydzi nie zdążyli się zorientować, o co chodzi.

\section{Zeznanie Władysława Kolasy ${ }^{88}$}

Ci z kolei [„Grzegorz i „Zygmunt”] po przeprowadzeniu dłuższej rozmowy z „Zawiszą” zebrali swoje plutony, w skład których wchodziło sześć drużyn, tj. moja, „Żendziana” [sic!], „Bystrego”, „Olszy”, „Jastrzębia” i „Lecha” i wraz z tymi Żydami udaliśmy się w lasy siekierzyńskie prowadzeni przez tych Żydów. Po przybyciu na miejsce Żydzi ci zawołali dalszych pięćdziesięciu czterech Żydów, w skład których wchodziło osiem kobiet i dwoje dzieci. Wszyscy Żydzi ci wychodzili z szałasów, rzędem po dwoje i wg zapewnień „Bolroka” mieli być zapisani do org[anizacji] AK. W tym samym czasie „Bolrok” powiadomił żołnierzy drużyn prócz drużyny „Olszy”, która poszła na ubezpieczenie, aby ustawili się z tyłu za Żydami i w chwili gdy on podniesie rękę do góry mają oddać strzały w kierunku nich, co też żołnierze wykonali. Po oddaniu strzałów kilku z nich zostało tylko rannych, w związku z czym zostali podobijani. Po dokonaniu tego mordu z niektórych zabitych zostały pozdejmowane buty i ubrania, po czym z powrotem dołączyliśmy do oddziału.

${ }^{88}$ Ibidem, Protokół przesłuchania z 10 II 1949 r. w WUBP w Kielcach, starszy referent Ryszard Kuźdub, k. 101-102. 


\section{Zeznanie Władysława Kolasy ${ }^{89}$}

Dodaję, że w zabiciu Żydów sam osobiście nie brałem udziału, a idąc na miejsce egzekucji, działałem pod rozkazem dowódcy „Zawiszy”. Wyjaśniam, że za przeciwstawienie się rozkazowi groziła mi kula. Przypominam sobie, że porucznik „Grzegorz” mówił, że kto nie może patrzeć na egzekucję, niech się odwróci, a po zakończeniu powiedział, że było to niepotrzebne i że było to wielkie świństwo.

\section{Zeznanie Władysława Kolasy na rozprawie głównej ${ }^{90}$}

Do mnie, jak zeznałem, przyszedł goniec z poleceniem zostawienia ciężkiej broni i udania się wyłącznie z lekką bronią pod rozkazy „Grzegorza”. Zgodnie z rozkazem dołączyłem do plutonu, nie wiedząc zupełnie, dokąd idziemy. Prowadzili nas ci 4-ej Żydkowie. Pierwszą grupą dowodził „Bojrok”, a drugą „Grzegorz”. Całością dowodził „Grzegorz”. Na dwie grupy rozdzieliliśmy się dopiero wówczas, gdy dowiedzieliśmy się, że idziemy likwidować Żydów. Ja dowiedziałem się o tym fakcie dopiero wówczas, gdy „Grzegorz” wezwał oficerów i zapytał ich, kto się podejmie likwidować znajdujących się w lesie Żydów. Wtedy zgłosił się na ochotnika „Bojlrok”, który podobierał sobie sam ludzi. Następnie „Bojlrok” z wybranymi ludźmi udał się na polanę, gdzie obozowali Żydzi, potem prowadził ich jeszcze z 500 metrów w las i ustawił ich na skraju lasu. Było tam może z 50 Żydów, w tym 4 kobiety. Podchorąży „Olsza” prosił, aby jemu pozwolić odejść, na co uzyskał zgodę. Zresztą „Grzegorz” sam powiedział, że jeśli kto nie może na to patrzeć, może odejść i sam ze Stecem odszedł również. Wyznaczeni żołnierze dali ognia do Żydów już ustawionych. Tych 4-ch zatrzymanych Żydów, którzy nas prowadzili, też dołączyli do grupy Żydów. Następnie Żydzi byli rozebrani z ubrania i z butów, trupy ułożono na stosie i tak zostawiono. Po tej sprawie „Grzegorz” w oddziale mówił do nas, że o ile „Zawisza” wydał sam ten rozkaz, to zrobił on wielkie świństwo, bo tak nie robia żołnierze. Był na to bardzo oburzony. Żołnierze zaś biorący udział w tym zastrzeleniu tłumaczyli się, że oni mieli wykonać rozkaz. Tę grupę 4-ch Żydów, którzy prowadzili nas zlikwidował na końcu „Bojlrok”. Oskarżony Stec nie udzielał się wtedy wcale, był z dala od tego zajścia. Sternik, Górski, Śledź, Kawecki i Stec byli wtedy w lesie, ale czy oni strzelali, nie wiem, bo tego nie widziałem.

\section{Zeznanie Edwarda Sternika ${ }^{91}$}

Po powrocie z ćwiczeń wezwał mnie do siebie dowódca oddziału por. „Zawisza” i oświadczył mi, że w lasach koło wsi, tzn. Siekierna, znajdują się Żydzi, których Niemcy rozpuścili z obozów i Żydów tych trzeba będzie wystrzelać, a jednocześnie polecił wyrok ten wykonać mnie, jako dowódcy plutonu. Przydzielając mi w tym

${ }^{89}$ Ibidem, Protokół przesłuchania 21 II 1949 r. przez p.o. podprokuratora L. Szelińską, k. 114-115.

${ }^{90}$ AIPN, GK, 217/45, Protokół rozprawy głównej przed Sądem Apelacyjnym w Kielcach w dniach 21-23 II 1950 r., k. 91.

${ }^{91}$ AIPN, GK, 411/216, Protokół przesłuchania z 10 VI 1949 r. w WUBP w Kielcach, oficer śledczy Marian Duda, k. 172-173. 
celu kilku ludzi z plutonu „Longina”. Przy tym nadmienił, że na miejsce, gdzie przebywają Żydzi, zaprowadzi nas jeden Żyd przebywający na jego kwaterze. Moim zastępcą był w tym czasie ppor. Stec Jan ps. „Zygmunt”, przy pomocy którego sformowałem pluton, dołączając do niego przydzielonych ludzi z plutonu „Longina” i innych. Zgodnie z poleceniem dowództwo nad całością objąłem ja, mając do dyspozycji około sześćdziesięciu ludzi. Dowódcami drużyn w tym czasie byli: Kolasa ps. „Leń”, Górski ps. „Rzędzian”, Kawecki ps. „Lech” i jeśli się nie mylę „Olsza”. Poza tym było jeszcze kilku podoficerów z innych plutonów, jak np. „Bolrok”, podoficer broni w stopniu sierżanta i innych, których nie pamiętam. Czy byli oni jednak ochotniczo na tej akcji, czy też z polecenia "Zawiszy” nie jest mi wiadomem. Członkowie oddziału udający się na wspomnianą akcję zorientowani byli o celu akcji przez samego „Zawiszę”. W takim składzie udałem się za przewodnikiem Żydem, który prowadził nas na miejsce, zaprowadzając w las około pięciu kilometrów w kierunku zachodnim od wsi Siekierno. Podchodząc pod obóz, w którym Żydzi ci mieszkali, obóz ten został okrążony, a następnie ja, „Zygmunt” i kilku innych weszliśmy do środka obozu, który składał się z kilku szałasów. Byli to mężczyźni w różnym wieku życia oraz było między nimi kilka kobiet. Żydów tych, jak zorientowałem się, było około dwudziestu. Jak sobie przypominam, w tym czasie kiedy byłem w obozie, ze strony naszej obstawy słychać było strzały, gdzie został w rękę postrzelony jeden Żyd. Kto to jednak zrobił, obecnie sobie nie przypominam. Następnie z mojego rozkazu sierżant „Bolrok” dobrał do siebie kilku odpowiednich ludzi, przy pomocy których ludzi tych (Żydów) wyszeregował w czwórki, wyprowadził na polanę w lesie i wszystkich wystrzelał. Ja osobiście do Żydów tych nie strzelałem, lecz jak poszedłem na polane po dokonaniu egzekucji widok był bardzo wstrząsający i leżeli oni na polanie postrzelani, tak mężczyźni, jak i kobiety. Następnie ja dałem rozkaz dokonania koło nich rewizji, a pościągane buty i ubrania odstawić furmanką do oddziału, co zostało wykonane. Ja przyjąłem nawet od żołnierzy wtedy kilka dolarów amerykańskich, które znaleźli przy zabitych Żydach, lecz po powrocie na kwatery oddałem je „Zawiszy”, razem z innymi przedmiotami zabranymi z akcji. Co to byli za Żydzi i jakim sposobem oni znaleźli się w tym lesie, nie jest mi wiadomem, bo nawet będąc w ich szałasach, nie rozmawiałem $z$ nimi.

\section{Zeznanie Edwarda Sternika ${ }^{92}$}

Odnośnie [do] faktu rozstrzelania w lasach siekierzyńskich obywateli polskich narodowości żydowskiej wyjaśniam co następuje: w 1944 roku dowódca mój bezpośredni „Zawisza” wezwał mnie do siebie i powiedział, że w lasach siekierzyńskich jest koncentracja oddziałów AK, że Niemcy rozpracowują to zgrupowanie i dlatego wysłali do lasów oddział Żydów, którzy mieli zadanie dopomóc Niemcom rozpracowanie oddziałów. Mówił, że ma jednego członka z tej grupy, który zaprowadzi do lasu i wskaże miejsce ich pobytu i że tę grupę należy zlikwidować. Prosiłem „Za-

${ }^{92}$ AIPN, GK, 411/216, Protokół przesłuchania z 25 VIII 1949 r., podprokurator Sądu Okręgowego w Kielcach M. Górski, k. 174. 
wiszę” o zwolnienie mnie od wykonania tego rozkazu, ale ponieważ „Zawisza” nie zgodził się, rozkaz musiałem wykonać. Po przybyciu na miejsce zebraliśmy Żydów. Ja porozumiałem się z pseudo „Bolrokiem”, pytając, czy będzie zdolny wykonać ten rozkaz. „Bolrok” się zgodził i ja odszedłem. Jak „Bolrok” wykonał ten rozkaz, nie mogę opisać, gdyż tego nie widziałem.

\section{Zeznanie Edwarda Sternika na rozprawie głównej ${ }^{93}$}

W pewnej chwili wezwał mnie do siebie „Zawisza” i oświadczył, że w lesie siekierzyńskim znajduje się grupa ludzi prawdopodobnie Żydzi, która donosi Niemcom o działalności AK i działa na naszą szkodę, wobec tego trzeba zebrać grupę ludzi w sile jednego plutonu i [z] innych oddziałów i pójść z nimi do lasu w Siekierzynie. Gdy usłyszałem rozkaz, że mam iść na egzekucję i likwidację, gdyż tak wyraźnie powiedział mi „Zawisza”, że trzeba tych ludzi zlikwidować, zwróciłem się wtedy do niego, żeby mnie zwolnił z tego obowiązku, gdyż tego zrobić nie podejmuję się, wyjaśniając mu jednocześnie, że przyszedłem do lasu, aby walczyć w otwartej walce z Niemcami, a nie z bezbronnymi ludźmi. „Zawisza” nie chciał mnie jednak zwolnić i kazał bezwzględnie wykonać jego rozkaz. Polecił on nam zabrać z sobą tylko pistolety maszynowe. Rozkaz ten „Zawisza” wydał mnie, Stec był wtedy na ćwiczeniach polowych, zabrałem więc swój pluton i te dołączone do niego i maszerowałem. Po drodze dołączył do mnie Stec z żołnierzami i dalej maszerowaliśmy. Prowadził nas wtedy na miejsce jeden młody człowiek, nie wiem, czy to był Żyd. W lesie zauważyliśmy szałasy i prawdopodobnie wtedy dałem rozkaz okrążenia ich. Wtedy dopiero powiedziałem żołnierzom, że z rozkazu „Zawiszy” mamy zlikwidować tę grupę i kto zgłasza się do tego na ochotnika. Wystąpił wtedy Bojlrok, wyrażając zgodę na wykonanie tego rozkazu. Przed tym zapytałem Śledzia, który stanowczo odmówił. Nie wiem, jak dalej wyglądała ta likwidacja, bo ja zaraz odszedłem i udałem się w las. Olszę, który także prosił o zwolnienie, zwolniłem. Po wykonaniu egzekucji wróciłem i powtórzyłem rozkaz „Zawiszy” zdjęcia z zabitych butów i ubrania, ponieważ byli w naszym oddziale ludzie, którzy nie mieli obuwia. W czasie tego zdejmowania butów przyszedł goniec od „Zawiszy”, aby natychmiast wracać do kwatery, bo oddział jest zagrożony przez Niemców. Zebrałem więc ludzi z powrotem i bezzwłocznie pomaszerowaliśmy do oddziału AK. Wiem, że ten rozkaz był niesłuszny. Zastanawiałem się nad tym rozkazem. Byłem na rozdrożu, czy ci ludzie są rzeczywiście winni czy nie. Zawisza mówił mi, że są to ludzie, którzy mają rozpracowywać działalność AK. Już wtedy wydawała mi się ta podstawa dziwna, najlepszy dowód tego, że prosiłem dowódcy o zwolnienie mnie z tego obowiązku. Z drugiej zaś strony, gdy nie zostałem przez „Zawiszę” zwolniony, wiedziałem, że rozkaz dowództwa musi być wykonany, nie mogłem więc go nie wykonać. Spełniłem tylko to, co musiałem, niewykonywanie bowiem rozkazu groziło sądem polowym. Dziś doszedłem do wniosku, że jestem w tej sprawie niewinien, gdyż

${ }^{93}$ AIPN, GK, 217/45, Protokół rozprawy głównej przed Sądem Apelacyjnym w Kielcach w dniach 21-23 II 1950 r., k. 92. 
sprzeciwiałem się „Zawiszy” w pójściu na tę akcję i prosiłem go, aby mnie zwolnił. Pozostawało mi wtedy, gdy mnie nie zwolnił, aby wyciągnąć pistolet i odebrać sobie życie, albo pójść. Nie chciałem osobiście jednak brać udziału w tym zabójstwie, nie chciałem nikogo zmuszać do brania udziału, dlatego który mnie prosił o zwolnienie, zwalniałem. Idąc do lasu, wiedziałem, że idę zlikwidować grupę ludzi, wśród których może i są Żydzi. Wiedziałem, że szliśmy do tej prawdziwej grupy, bo prowadził nas przewodnik, który, jak mówił „Zawisza”, był też z tej grupy. Gdybym wiedział, że to są Żydzi i ludzie niewinni, to grubo zastanawiałbym się nad wykonaniem rozkazu. W czasie egzekucji nie byłem jeszcze zupełnie pewny, czy wszyscy ci ludzie są Żydzi, bo było to w lesie, gdzie widoczność była mniejsza. Nie rozmawiałem także z nimi i nie miałem rozkazu przeprowadzać z nimi żadnych badań. „Zawisza” nie mówił mi, że są to ludzie, którzy uciekli z obozu niemieckiego. Było wśród nich kilka kobiet, ale dzieci nie widziałem. [...] Nie myślałem wtedy nad tym, [czy] zastrzelenie tych ludzi było pójściem na rękę władzy niemieckiej. Ja Niemcom tej pomocy nie udzielałem. Do AK poszedłem po to, aby walczyć w otwartej walce $z$ Niemcami. O ile wykonywałem inne roboty, to działałem tylko $z$ rozkazu. [...] Nie umiem na to odpowiedzieć, czy sąd polowy uwolniłby mnie od kary za niewykonanie takiego rozkazu dowódcy. Regulaminu Wewnętrznego Wojska Polskiego nie pamiętam. Podchorążówkę skończyłem w roku 1936. Trudno mi w tej chwili odpowiedzieć na pytanie Pana Prokuratora, czy wybrałbym wyrok śmierci sądu polowego, czy wyrok sądu dziś.

\section{Zeznanie Jana Górskiego ${ }^{94}$}

Wracając po południu z ćwiczeń na kwatery, spotkaliśmy na drodze „Grzegorza”, który czekał na nas z resztą swojego plutonu i kilkoma innymi ludźmi z kompanii. „Grzegorz” zatrzymał nas i rozkazał nam dołączyć, gdzie szliśmy około 5-6 km w las. Początkowo gdzie i po co idziemy, nie wiedziałem. Prowadził nas jeden czy dwóch Żydów, którzy szli na przedzie oddziałów. Dowództwo nad całością miał ppor. „Grzegorz”. Kiedy podeszliśmy w pobliże obozu, w którym przebywali Żydzi, „Grzegorz” polecił nam rozbić się na dwie grupy, z których jedną dowodził on, a drugą „Zygmunt”. Wtedy też powiedziano nam, że idziemy do obozu, w którym znajdują się Żydzi i zostaną oni rozstrzelani, tylko dokładnie sobie nie przypominam, w której grupie ja się wtedy znalazłem, a jeśli się nie mylę, w grupie „Zygmunta”, i weszliśmy prosto do obozu. Natomiast grupa „Grzegorza” okrążyła z drugiej strony obóz i też weszła częściowo do obozu, tak że „Grzegorza” widziałem wtedy w obozie. W tym czasie kiedy „Zygmunt”, będąc w obozie, mówił do Żydów, że jak chcą mogą iść z nami do oddziału z boku odezwały się strzały i jak się okazało „Bolrok” (sierżant) puścił serię z automatu, raniąc dwóch Żydów, którzy prawdopodobnie chcieli uciekać, za co oczywiście skrzyczał go na boku „Grzegorz”, bo było za wcześnie. Tych dwóch rannych oraz dwóch innych, którzy ich

${ }^{94}$ AIPN, GK, 411/216, Protokół przesłuchania z 11 V 1949 r. w WUBP w Kielcach, oficer śledczy Marian Duda, k. 186-187. 
opatrywali z polecenia „Grzegorza”, pozostawiono na boku, i „Grzegorz” rozkazał mnie, „Jordanowi” i trzeciemu, którego nie znałem, ich pilnować, aby nie uciekli, a kiedy odezwą [się] strzały, należy ich zastrzelić. Pozostała część Żydów zgodnie z oświadczeniem „Zygmunta” pod pretekstem przyjęcia ich do oddziału została uszeregowana i w trakcie marszu rozstrzelana. Ja natomiast będąc wraz $\mathrm{z}$ ww. przy wspomnianych czterech Żydach, kiedy odezwały się strzały, Żydów tych zastrzeliłem. Zgodnie z poleceniem „Grzegorza” przy czterech zastrzelonych Żydach przeprowadziliśmy rewizję, a znalezione kilkaset złotych i jedną parę butów oddano „Grzegorzowi”. Ile Żydów tych zostało zastrzelonych trudno jest dokładnie określić, ja przypuszczam, że około czterdziestu czy pięćdziesięciu, w tym kilka kobiet i jedno czy dwoje dzieci. Rewizja została przeprowadzona też i u pozostałych Żydów, a zabrane ubrania i buty odtransportowano do oddziału. Trupów tych ściągnięto z polany na brzeg lasu i tak pozostawiono, nie zakopując ich.

\section{Zeznanie Jana Górskiego na rozprawie głównej ${ }^{95}$}

W pewnej chwili usłyszałem kilka strzałów, jak się okazało „Bojlrok” postrzelił kilku Żydów, którzy szli z nami jako przewodnicy. „Grzegorz” zwrócił się wtedy do Bojlroka z wymówką, dlaczego strzela na własną rękę. Ranni, których postrzelił „Bojlrok”, pozostali na miejscu - nikt ich nie opatrywał i mnie, nie pamiętam „Grzegorz” czy „Bojlrok”, kazał ich pilnować z kilku żołnierzami, przy czym otrzymałem rozkaz, aby w chwili gdy w lesie będzie egzekucja, zastrzelić tych 4-ch czy 5-ciu, przy których mnie pozostawiono. Zgodnie z rozkazem ja z „Jordanem” i jeszcze kimś pozostałem, a reszta oddziału poszła naprzód. Jak się tam odbyła egzekucja, nie wiem, gdyż tam nie byłem. W chwili gdy usłyszeliśmy w lesie strzały, jeden z moich żołnierzy, zdaje się „Jordan”, zastrzelił tych 4-ch pozostawionych przy nas Żydów. Ja wówczas nie strzelałem do nich. Wydanie takiego rozkazu zastrzelenia ich padło, zdaje się, na odprawie, gdy „Bojlrok” już zgłosił się na ochotnika do wykonania rozkazu, raczej więc „Bojlrok” wydał mi ten rozkaz zastrzelenia tych 4-ch. Z polecenia „Grzegorza” ściągnęliśmy z zabitych buty i dokonali rewizji w ubraniach. Gdy potem poszedłem na miejsce egzekucji, zobaczyłem około 50 trupów, w tej liczbie były, zdaje się, i kobiety i dzieci też. Jeszcze raz wyjaśniam, że ja nie strzelałem do 4-ch Żydów, a tylko żołnierze, którzy byli ze mną.

\section{Zeznanie Jana Steca na rozprawie głównej ${ }^{96}$}

Weszliśmy na polanę, gdzie zobaczyliśmy szałasy, z których powychodzili ludzie. Odprawy wówczas żadnej nie było. Nie wiedziałem dokładnie, co będziemy robić. [...] Zorientowaliśmy się, że to są Żydzi. Zwróciłem się do „Grzegorza”, że może dałoby się tego rozkazu nie wykonać, na co „Grzegorz” odpowiedział mi, że „Zawisza” wydał bezwzględny rozkaz. „Grzegorz” zwrócił się wtedy do wszystkich,

${ }^{95}$ AIPN, GK, 217/45, Protokół rozprawy głównej przed Sądem Apelacyjnym w Kielcach w dniach 21-23 II 1950 r., k. 92.

${ }^{96}$ Ibidem, k. 93. 
kto podejmie się wykonać go. Zgłosił się „Bojlrok” i kilku ochotników. Ja już nie patrząc, co dalej się działo, odszedłem, tak że nie wiem, w jaki sposób odbywała się sama egzekucja. Nie brałem w niej żadnego udziału, odszedłem w las. Gdy maszerowaliśmy do lasu, to widziałem na czele kolumny 2-ch przewodników, ale kim byli ci ludzie nie wiedziałem. [...] Wiem, że „Grzegorz” nie „delektował” się tym czynem. Przyjął to jako konieczność spowodowaną twardym i bezwzględnym rozkazem Zawiszy.

\section{Zeznanie Jana Śledzia na rozprawie głównej97}

„Grzegorz” powiedział nam, jaki mamy wykonać rozkaz i zwrócił się do mnie z zapytaniem, czy podejmuję się wykonać ten rozkaz. Odpowiedziałem mu, że ja do tego ręki nie przykładam i odszedłem na bok. Wtedy zgłosił się na ochotnika „Bojlrok”, który zaraz objął dowództwo w tej akcji. [...] Ilu tam było wtedy zastrzelonych Żydów, trudno mi odpowiedzieć. W oddziale mówili potem, że podobno miały tam być i dzieci. Ta sprawa ujemnie wpłynęła na ludzi z oddziału, widać było wielkie niezadowolenie i dlatego może się mało o tym mówiło. [...] „Grzegorzowi” na odprawie wyraźnie odmówiłem brania czynnego udziału w tej akcji, z którą nie mogłem się zgodzić, nie miałem z tego tytułu żadnych represji. [...] Nie wydał on [Sternik] bowiem rozkazu wojskowego, którym byłbym bezwzględnie związany, tylko zapytał, czy nie zgłosiłbym się sam. Gdy odmówiłem, nie miałem z tego tytułu żadnych od niego ani od innych osób przykrości. Po tych wypadkach w lasach siekierzyńskich „Zawisza” odszedł z naszego oddziału, został on zabrany przez dowództwo obwodu prawdopodobnie. W oddziale mówiono, że ta sprawa z Żydami zaszkodziła mu bardzo. Kim był „Zawisza”, nie wiem.

\section{Zeznanie Władysława Cybuli na rozprawie głównej ${ }^{98}$}

Po tym wypadku w lesie siekierzyńskim widziałem u „Bojlroka” jakieś buty. Pierścionków ja osobiście u niego nie widziałem, tylko mówił mi o tym żołnierz „Wampir”. Pierścionki te rzekomo zostały „Bojlrokowi” potem skradzione. Przypuszczam, że szeregowiec „Wampir” był w akcji w Siekierzynie i wiedział, że stamtąd te pierścionki ma „Bojlrok”.

\section{Noty biograficzne ${ }^{99}$}

Władysław Cybula (vel Cebula), „Grzmot” (1921-?), z Bodzechowa, rolnik na własnym gospodarstwie. Ukończył 7 klas. W AK od kwietnia 1943 r., zwerbowany przez Józefa Radomskiego „Robaka”, później w oddziale „Topora” i „Zawiszy”, w drużynie Kolasy jako celowniczy RKM, później w plutonie „Longina”. Po wojnie

\footnotetext{
${ }^{97}$ Ibidem, k. 94 .

${ }^{98}$ Ibidem.

${ }^{99}$ Wszystkie biogramy opracowano na podstawie zeznań własnych danej osoby, zeznań świadków, dokumentów procesowych oraz dostępnej literatury przedmiotu.
} 
pracował na roli, od 1949 r. był członkiem Zjednoczonego Stronnictwa Ludowego. Brał udział w zabójstwie Żydów w Goździelinie. Skazany przez Sąd Apelacyjny w Kielcach 25 lutego 1951 r. na karę „dożywotniego więzienia, utratę praw publicznych i obywatelskich praw honorowych na zawsze oraz przepadek całego mienia"100. Ten sam wyrok otrzymali Władysław Kolasa i Ryszard Nowacki. 11 września 1950 r. zaskarżony wyrok został utrzymany w mocy przez Sąd Najwyższy w Warszawie ${ }^{101}$. Sąd Najwyższy w Warszawie postanowieniem z 19 stycznia 1957 r. zmniejszył wyrok Cybuli do 10 lat więzienia. Trzy miesiące później, 15 marca 1957 r., Sąd Wojewódzki w Kielcach na wniosek prokuratora i na podstawie dobrej opinii z więzienia orzekł jego warunkowe i przedterminowe zwolnienie. 21 stycznia 2000 r. Sąd Okręgowy oddalił wniosek Cecylii Cybuli z 20 lipca 1998 r., w którym domagała się stwierdzenia nieważności wcześniejszych orzeczeń.

Jan Górski, „Rzędzian” (1922-), pochodził ze wsi Jagnin pow. Opatów, urodził się w rodzinie ziemiańskiej. Po wojnie zamieszkał w Poznaniu i studiował na Akademii Medycznej. Do ZWZ-AK wstąpił w czerwcu 1942 r., potem był w oddziale „Mruka”, następnie „Topora” i „Zawiszy”. U „Topora” był dowódcą drużyny, u „Zawiszy” zastępcą dowódcy plutonu - aż do zdemobilizowania. Tuż po wojnie aresztowany na krótko przez UB pod zarzutem przynależności do Zrzeszenia „Wolność i Niezawisłość”. Sądzony, wraz z pięcioma innymi oskarżonymi, przez Sąd Apelacyjny w Kielcach za zbrodnię w lasach siekierzyńskich, otrzymał najsurowszy wyrok - karę śmierci. W drodze łaski kara ta została zamieniona na dożywotnie więzienie. 11 września 1950 r. wyrok został utrzymany przez Sąd Najwyższy. 12 grudnia 1957 r. Sąd Najwyższy, po rewizji nadzwyczajnej wniesionej przez prokuratora generalnego PRL, złagodził wyrok do ośmiu lat pozbawienia wolności; jednocześnie zaliczył Górskiemu na poczet kary okres aresztowania i pobytu w więzieniu od 28 kwietnia 1949 r., uznając tym samym karę za odbytą.

Stanisław Kawecki, „Lech” (1919-?), pochodził z Chocimowa pow. Opatów, urodził się w rodzinie ziemiańskiej. Wstapił do oddziału „Mruka” w lutym 1944 r., po dwóch dniach dowódcę zastąpił „Topór”. „Lech” był tam w stopniu strzelca w drużynie „Gryfa”, potem „Mikołaja” - Rosjanina. Po wojnie pracował w wydziale drogowym w Zarządzie Miejskim, uczył w szkole, pracował w zawodzie technika w Starachowicach (w górnictwie) oraz społecznie w związkach zawodowych. Za udział w morderstwie na Żydach w lasach siekierzyńskich został skazany przez Sąd Apelacyjny w Kielcach na 8 lat więzienia ${ }^{102}$. Wyrok ten został utrzymany w mocy przez Sąd Najwyższy 11 września 1950 r. Postanowieniem z 28 lipca 1993 r. Sąd

${ }^{100}$ AIPN, GK, 217/45, Sentencja wyroku Sądu Apelacyjnego w Kielcach z 25 II 1951 r., k. 215.

${ }^{101}$ Ibidem, GK, 217/46, Sentencja wyroku Sądu Najwyższego w Warszawie z 11 IX 1950 r., k. 8-22.

${ }^{102}$ AIPN, GK, 217/45, Sentencja wyroku Sądu Apelacyjnego w Kielcach z 25 II 1951 r., k. 135. Za udział w akcji przeciwko oddziałowi AL w styczniu 1944 r. w Wólce Bodzechowskiej otrzymał karę 5 lat i 6 miesięcy więzienia. Wyrok łączny opiewał na 10 lat. 
Wojewódzki w Kielcach nie uwzględnił wniosku Stanisława Kaweckiego o unieważnienie skazania za udział $\mathrm{w}$ tej zbrodni. Postanowienie to utrzymał $\mathrm{w}$ mocy także Sąd Apelacyjny w Krakowie. Obrońca skazanego wystapił następnie o wznowienie postępowania w sprawie wyroku Sądu Apelacyjnego (z 25 lutego 1950 r.) i Sądu Wojewódzkiego (28 lipca 1993 r.) w Kielcach. Sąd Najwyższy postanowieniami z 16 lutego 1996 i 10 lutego 1999 r. wnioski te oddalił. W latach następnych pełnomocnicy Kaweckiego nie ustawali w wysiłkach mających na celu oczyszczenie swojego klienta; ich starania pozostały jednak bezowocne ${ }^{103}$.

Władysław Kolasa, „Leń” (1909-?), urodził się w Grójcu pow. Opatów, zamieszkały w Opatowie, ukończył dwa kursy seminarium nauczycielskiego. Po wojnie pracował jako magazynier. W ZWZ-AK od listopada 1942 r. w oddziale stanowiącym ochronę majątku Kaliszany, gdzie stacjonował sztab AK. Kolasa był tam w plutonie porucznika „Dęba”; podlegali Oddziałowi II (wywiad). Potem w oddziale „Topora” i „Zawiszy”, jako dowódca drużyny w stopniu kaprala. Po wojnie za nielegalne przechowywanie broni skazany przez Wojskowy Sąd Rejonowy w Kielcach na dożywocie. Za udział w zabójstwie Żydów w Goździelinie oraz w lasach siekierzyńskich Sąd Apelacyjny w Kielcach 25 lutego 1951 r. skazał go na łączną karę „dożywotniego więzienia, utratę praw publicznych i obywatelskich praw honorowych na zawsze oraz przepadek całego mienia" ${ }^{104}$. Wyrok został utrzymany w mocy przez Sąd Najwyższy w Warszawie ${ }^{105} .13$ marca 1957 r. Sąd Wojewódzki w Kielcach zmniejszył karę łączną Kolasie (także skazanemu Nowackiemu) do 10 lat więzienia i zaliczył na poczet kary aresztowanie i pobyt $\mathrm{w}$ zakładzie penitencjarnym od 20 stycznia 1949 r.

103 „Obecnie obrońca skazanego - czytamy w postanowieniu Sądu Najwyższego z 21 X 1999 r. - złożył kolejny wniosek o wznowienie postępowania, domagając się uchylenia wyroku Sądu Najwyższego z dnia 11 września 1950 r., sygn. K 783/50, oraz utrzymanego nim w mocy wyroku b[yłego] Sądu Apelacyjnego w Kielcach z dnia 25 lutego 1950 r., sygn. I K 108/49, skazującego Stanisława Kaweckiego za czyn z art. 1 dekretu z 31 VIII 1944 r. na karę 8 lat pozbawienia wolności oraz kary dodatkowe i przekazanie sprawy właściwemu sądowi do ponownego rozpoznania. Podstawą kolejnego wniosku są według obrońcy nowe dowody z zeznań świadków Jana Ziółkowskiego i Jana Pękalskiego, którzy mogą zeznać, iż «skazany nie podlegał w dniach od 14 do 16 sierpnia 1944 r. dowódcy grupy Edwardowi Sternikowi, a tym samym nie mógł i nie brał udziału w likwidacji osób narodowości żydowskiej»”. Sąd Najwyższy wniosek ten uznał za bezzasadny. Stwierdził jednocześnie, że „pogląd wyrażony przez Sąd Najwyższy w postanowieniu z dnia 10 lutego 1999 r., sygn. IV KO 90/98, zasługuje w pełni na aprobatę, podobnie jak i pogląd prezentowany we wcześniejszym postanowieniu z dnia 16 lutego 1996 r., sygn. III KO 43/95, w którym Sąd Najwyższy oddalając wniosek o wznowienie postępowania, skonstatował, iż nawet potwierdzenie wykonania przez Stanisława Kaweckiego prywatnego zadania zleconego przez dowódcę zgrupowania nie wykluczało udziału skazanego w zdarzeniu przypisanym mu w pkt. VI b wyroku b[yłego] Sądu Apelacyjnego w Kielcach z dnia 25 lutego 1950 r.” (ibidem, k. 7-9).

${ }^{104}$ AIPN, GK, 217/45, k. 215.

${ }^{105}$ Ibidem, 217/46, k. 8-22. 
Ryszard Nowacki, „Pobożny” (1921-?), pochodził z Ćmielowa, z zawodu kupiec, ukończył 4 klasy gimnazjum kupieckiego. Do Polskiego Związku Powstańczego wstapił w 1940 r., od 1942 r. w ZWZ-AK, podlegał Oddziałowi II na terenie Ćmielowa (Józefowi Radomskiemu „Robakowi”). W grudniu 1943 r. został skierowany do obstawy majątku Kaliszany. Po wojnie skazany przez Wojskowy Sąd Rejonowy w Kielcach na 15 lat więzienia za przynależność do WiN. Brał udział w zabójstwie Żydów w Goździelinie, za co przez Sąd Apelacyjny w Kielcach został skazany na karę „dożywotniego więzienia, utratę praw publicznych i obywatelskich praw honorowych na zawsze oraz przepadek całego mienia”106. 11 września $1950 \mathrm{r}$. zaskarżony wyrok został utrzymany w mocy przez Sąd Najwyższy w Warszawie ${ }^{107}$. 22 maja 1951 r. Sąd Wojewódzki w Kielcach wydał wyrok łączny: dożywotnie więzienie. Do sprawy powrócono po amnestii z 27 kwietnia 1956 r. 13 marca 1957 r. Sąd Wojewódzki w Kielcach zmniejszył Nowackiemu (i Kolasie) karę łączną do 10 lat więzienia i zaliczył na poczet kary aresztowanie i pobyt w zakładzie penitencjarnym od 25 listopada 1946 r.

Kazimierz Olchowik, „Zawisza” (1910-1979), urodził się w Grodnie, woj. białostockie. W 1929 r. ukończył Państwowe Gimnazjum Męskie im. A. Mickiewicza w Grodnie, a następnie przez trzy trymestry studiował na Wydziale Lekarskim Uniwersytetu Stefana Batorego w Wilnie. Po odbyciu w latach 1932-1933 obowiązkowej służby wojskowej podjął pracę w więziennictwie; był pomocnikiem naczelnika więzienia we Lwowie (Brygidki), a od 1936 r. pełnił funkcję naczelnika więzienia w Dobromilu (woj. lwowskie). 1 stycznia 1935 r. awansowany na podporucznika rezerwy. 23 sierpnia 1939 r. został zmobilizowany do 5. Pułku Strzelców Podhalańskich w Przemyślu, który w kampanii wrześniowej walczył w składzie 22. Dywizji Piechoty Górskiej (Armia Kraków). Olchowik jako dowódca plutonu i zastępca dowódcy kompanii brał udział w bitwie pod Owczarami k. Buska-Zdroju. 9 września 1939 r. miał być według własnych słów awansowany na porucznika, dzień później pod Rytwianami dostał się do niewoli niemieckiej. Przebywał w niej przez 6 tygodni (od 10 września do 27 października), po czym został zwolniony. Ukrywał się jako oficer nierejestrowany na terenie pow. opatowskiego. W październiku 1942 r. wstapił do Armii Krajowej i przydzielono go do Ekspozytury (Oddziału) II Okręgu Radom z zadaniem zorganizowania wywiadu i bojówki. W maju 1943 r. został odkomenderowany w Góry Świętokrzyskie, gdzie między innymi prowadził szkolenie żołnierzy AK w Podobwodzie Ostrowiec Świętokrzyski (kryptonim „100”). 18 lutego 1944 r. został aresztowany przez Niemców i osadzony w więzieniu w Ostrowcu Świętokrzyskim. Po kilku dniach Niemcy zwolnili go. Swoim kolegom opowiadał, że oddano mu broń (!),według zeznań Władysława Kolasy powołał się na „Mruka”. Jego znakiem rozpoznawczym były blizny na obu nadgarstkach, powstałe w wyniku próby samobójczej w areszcie gestapo. Po wyjściu z więzienia pod koniec lutego 1944 r. wstąpił do

\footnotetext{
${ }^{106}$ Ibidem, 217/45, k. 215.

${ }^{107}$ Ibidem, 217/46, k. 8-22.
} 
oddziału „Barwy Białe”, gdzie pełnił funkcję oficera szkoleniowego, a po odwołaniu „Topora” zastąpił go od 1 kwietnia 1944 r. na stanowisku dowódcy oddziału. Oddział „Zawiszy” w sile około 250 ludzi wszedł w skład 2. pp Leg. AK; Olchowik był dowódcą 5. kompanii do 1 września 1944 r. Po rozwiązaniu 2. pp Leg. 12 października 1944 r. Olchowik został wyznaczony na dowódcę 2 . batalionu z zadaniem przeprowadzenia go w rejon Gór Świętokrzyskich i rozformowania oddziału. Pod koniec grudnia 1944 r. „Zawisza” pojawił się w domu Kolasy, ubrany po cywilnemu, i pokazywał mu parabellum oraz pozwolenie niemieckie na jej posiadanie. 8 stycznia 1946 r. opuścił Polskę i przedostał się do Murnau (Bawaria, pod administracją amerykańska), gdzie przeszedł weryfikację wstępną przed Komisją Weryfikacyjną Żołnierzy AK. Stamtąd skierowany został do Polskiego Okręgu Wojskowego na terenie Szlezwika-Holsztynu, w Wentorf (brytyjska strefa okupacyjna), tam przeszedł kolejną weryfikację. Ostatecznie zaliczono mu służbę w konspiracji od 1 października 1942 do 15 stycznia 1945 r. a także stopień porucznika, uzyskany w czasie wojny. Z Niemiec Olchowik przedostał się do Anglii, skąd wyjechał do Australii, gdzie zmarł.

Józef Radomski, „Konrad”, „Robak” (1907-?), urodził się w Krasnojarsku (Rosja), zdobył wykształcenie średnie ekonomiczne, pochodził z rodziny robotniczej. Szef Oddziału II AK w Ćmielowie, jego zastępcą był „Grażyna”. Po wojnie mieszkał w Starachowicach, pracował jako rewident w Spółdzielni Pracy w Kielcach.

Stanisław Różalski, „Grażyna” (1902-?), miał pochodzenie chłopskie, ukończył 7 klas szkoły podstawowej. Brał udział w wojnie polsko-bolszewickiej $1920 \mathrm{r}$. Dwa lata pracował na Kresach przy wyrębie lasów i budowie domów, w 1923 r. został powołany do wojska, służył jako podoficer zawodowy do 1939 r. Uzyskał stopień sierżanta. Do konspiracji wciągnięty w 1941 r. przez „Kościeszę” (N.N.). Podczas przesłuchań twierdził, że początkowo nie wiedział, do jakiej organizacji należał. Podczas okupacji mieszkał w Ćmielowie, prowadził sklepik z piwem i słodyczami, utrzymywał $\mathrm{w}$ nim konspiracyjną skrzynkę kontaktową. Był zastępcą Radomskiego „Robaka” - szefa „dwójki” w Ćmielowie. W końcu grudnia $1944 \mathrm{r}$. aresztowany przez gestapo w Ostrowcu, po interwencji „Robaka” zwolniony. Brał udział w zabójstwie Żydów w Goździelinie. Po 1945 r. ukrywał się, pracował jako chałupnik - wyrabiał i sprzedawał drobną galanterię z tkanin. Dopiero w 1959 r. ustalono jego miejsce pobytu (Legionowo, pow. Nowy Dwór Mazowiecki) i postawiono w stan oskarżenia. 26 lutego 1959 r. Prokuratura Wojewódzka w Kielcach wydała postanowienie o jego tymczasowym aresztowaniu. Wyrokiem Sądu Wojewódzkiego w Kielcach Oddział Zamiejscowy w Radomiu z 25 marca 1960 r. został skazany na 7 lat więzienia i 3 lata pozbawienia praw publicznych. Złożył rewizję od wyroku, wnosząc o złagodzenie orzeczonej kary z uwagi na to, że „wychowany był w duchu ślepego wykonywania rozkazów". 11 listopada 1960 r. Sąd Najwyższy w Warszawie uznał, że rewizja oskarżonego Różalskiego nie jest zasadna ${ }^{108}$.

${ }^{108}$ AIPN Ra, 29/138, Akta w sprawie karnej Stanisława Różalskiego, k. 11. 
Kazimierz Rudziński (Rudnicki?), „Bolrok”, sierżant, pochodził z okolic Baćkowic lub Rakowa, w 1944 r. miał około 36 lat. Wstąpił do oddziału „Barwy Białe” w 1944 r. w Szumsku (Szumsko-Raków), od razu objął funkcję podoficera broni. Z „Zawiszą” był na ty, mogli więc wcześniej się znać. Był prawdopodobnie podoficerem zawodowym w stopniu plutonowego. U dowódców AK cieszył się dużym zaufaniem. Brał udział w zbrodni na Żydach w lesie siekierzyńskim, nie był jednak sądzony. Jego powojenne losy są nieznane.

Witold Sągajłło, „Feliks”, „Sulima”, „Sandacz”, „Tarło” (1910-1998), od 1931 ppor. marynarki, od 3 maja 1935 r. por. marynarki. Od lutego 1940 r. w ZWZ Okręgu Radomsko-Kieleckiego; od maja 1941 do kwietnia 1944 r. komendant Obwodu Opatów ZWZ-AK (w 1943 r. awansowany na kpt. marynarki). We wrześniu 1945 r. przedostał się do Pragi czeskiej, gdzie zdobył pozwolenie na wyjazd do Pilzna w strefie amerykańskiej. Przebywał w obozach przejściowych w Cham, Regensburg i Murnau. 26 września 1946 wcielony jako kapitan do Marynarki Wojennej. Wyjechał do Anglii, mieszkał w Londynie (zob. wspomnienia: Witold Sagajllo, The Man in the Middle. A story of the Polish resistance 1940-45, London 1984, passim).

Jan Stec, „Zygmunt” (1912-?), urodził się w Prusach, pow. Opatów, urzędnik pochodzenia chłopskiego. W 1934 r. ukończył seminarium nauczycielskie, w 1935 r. odbył służbę wojskową, którą zakończył w stopniu podporucznika. Nie znalazł pracy jako nauczyciel i był zmuszony do 1939 r. pracować jako robotnik w Zakładach Starachowickich. Do organizacji podziemnej wstąpił na jesieni 1942 r., był zastępcą Edwarda Sternika, dowódcy plutonu. Do oddziału „Zawiszy” dołączył w lipcu 1944 r., był w nim łącznie tylko trzy tygodnie, potem przeszedł do innych oddziałów. W czasie wojny używał także dokumentów na nazwisko Wacław Kawiński. Wyrokiem z 25 lutego 1950 r. Jan Stec został skazany na 5 lat i 1 miesiąc więzienia za udział w zbrodni na Żydach w lesie siekierzyńskim. Sąd Najwyższy 11 września 1950 r. uniewinnił go od zarzutu udziału w tym przestępstwie. 14 listopada 1997 r. Sąd Okręgowy w Kielcach pozostawił bez rozpoznania wniosek Haliny Stec, w którym domagała się unieważnienia wyroku Sądu Apelacyjnego. 10 kwietnia 2000 r. Sąd Okręgowy w Kielcach przyznał rodzinie Steca (wdowie i dwójce dzieci) odszkodowanie od Skarbu Państwa w wysokości 2781 złotych na każdą osobę oraz zadośćuczynienie w wysokości 10 tys. złotych dla każdej z osób ${ }^{109}$.

Edward Sternik, „Majewski”, „Grzegorz” (1914-?), pochodził z Bodzechowa, pow. Opatów, tam też mieszkał przed wojną. Był oficerem WP sprzed 1939 r. w stopniu podporucznika, podchorążówkę ukończył w 1936 r.; brał udział w kampanii wrześniowej 1939 r. w walkach o Zamość jako zwykły żołnierz, pod Terespolem

${ }^{109}$ AIPN, GK, 217/45, k. 13. Rodzina Jana Steca domagała się kwoty 209502 zł tytułem zadośćuczynienia i odszkodowania za okres pozbawienia go wolności od 19 IV 1949 do 11 IX 1950 r. (ibidem, k. 14). 
został wzięty do niewoli, skąd uciekł. Z zawodu był nauczycielem. W czasie wojny posługiwał się także dokumentami na nazwisko Henryk Dębinak. W ZWZ-AK od początku 1940 r., w sześcioosobowej grupie Organizacja Walki Czynnej. Do oddziału „Zawiszy” wstąpił w maju 1944 r., pełnił funkcję oficera szkoleniowego i dowódcy plutonu. Po koncentracji AK był dowódcą I plutonu w 2. kompanii II Batalionu AK. W 1949 r. był kierownikiem szkoły powszechnej w Górzynie, pow. Krosno Odrzańskie; od 1946 r. członek PPS, potem PZPR. Za udział w mordzie na „Misiu” i zbrodni w lasach siekierzyńskich Sąd Apelacyjny w Kielcach 25 lutego 1950 r. skazał Sternika na karę śmierci. Bolesław Bierut 19 lutego 1951 r. karę śmierci zamienił na dożywotnie więzienie. Sąd Najwyższy 19 stycznia 1957 r. zmniejszył mu karę do 10 lat więzienia.

Konrad Suwalski, „Cichy”, „Mruk” (1917-1945), pochodził ze Śląska, mieszkał jednak w Ćmielowie. Jego ojciec był kierownikiem kopalni rudy żelaznej. Kilka lat przed wybuchem wojny „Mruk” ukończył Akademię Górniczą. Służył w WP, dochodząc do stopnia porucznika. Organizator i pierwszy dowódca oddziału „Barwy Białe”, którym dowodził do lutego 1944 r. Latem tego roku był w składzie 1. kompanii I Batalionu 2. pp Leg. AK, szedł na pomoc powstańczej Warszawie. W $1945 \mathrm{r}$. nie ujawnił się, ale już w kwietniu został rozpoznany na ulicy w Kielcach i aresztowany przez UB. Po kilku miesiącach ciężkich przesłuchań wytoczono mu proces przed Okręgowym Sądem Wojskowym w Łodzi na sesji w Kielcach. Został skazany na karę śmierci przez rozstrzelanie oraz pozbawienie praw obywatelskich, honorowych i publicznych na zawsze. Wyrok wykonano w sierpniu 1945 r. na cmentarzu żydowskim w Kielcach. Na początku lat dziewięćdziesiątych XX w. Konrad Suwalski został pośmiertnie zrehabilitowany i odznaczony Krzyżem Walecznych i Krzyżem AK.

Jan Szpinek, „Motyl” (1904-?), urodził się w Czachowie, pow. Opatów, w rodzinie robotniczej, ukończył 4 klasy gimnazjum. Zawodowy plutonowy, kierownik „dwójki” w Podobwodzie AK Ćmielów. Oskarżony o wydanie rozkazu dotyczącego wymordowania Żydów w Goździelinie. Sąd Wojewódzki w Kielcach 31 sierpnia 1944 r. skazał go na 10 lat więzienia oraz utratę praw publicznych i obywatelskich praw honorowych na okres 10 lat ${ }^{110} .8$ grudnia 1952 r. wyrok ów utrzymał w mocy Sąd Najwyższy w Warszawie. 6 marca 1958 r. ten sam Sąd Najwyższy, po rewizji nadzwyczajnej złożonej przez ministra sprawiedliwości, uchylił wyrok. W uzasadnieniu podano, że sąd pierwszej instancji opierał się jedynie „na wyjaśnieniach i zeznaniach świadka Stanisława Tworka”, które „nie mogły stanowić dostatecznego i przekonywającego dowodu co do winy oskarżonego".

${ }^{110}$ AIPN Ki, 9/126, k. 39. W procesie tym byli sądzeni członkowie kierownictwa II Oddziału ZWZ-AK Obwodu Opatów, między innymi Zenon Krzekotowski, Władysław Banaszak, Józef Radomski i Michał Pytlak. 
Jan Śledź, „Jeleń” (1918-?), urodził się w Jurkowicach, pow. Sandomierz, urzędnik, ukończył 6 klas gimnazjum. Do marca 1944 r. pracował w Zakładach Ostrowieckich jako spawacz. W partyzantce od marca 1944 r. jako starszy sierżant instruktor szkoleniowy. Po wojnie pracował w Zarządzie Miejskim w Szczecinie. W 1946 r. skazany przez Wojskowy Sąd Rejonowy w Szczecinie, wyszedł z więzienia w 1947. Za udział w mordzie na „Misiu” i w lasach siekierzyńskich skazany przez Sąd Apelacyjny w Kielcach 25 lutego 1950 r. na karę łączną 5 lat i 1 miesiąc więzienia.

Stanisław Tworek, „Jaszczurka” (1908-?), urodził się w Bodzechowie, ukończył 4 klasy gimnazjum, z zawodu ślusarz mechanik, w wojsku nie służył. Do ZWZ/AK wstąpił w grudniu 1941 r. Zbierał informacje, które dostarczał „Robakowi”; był też w AK instruktorem obsługi pojazdów mechanicznych. Po wojnie pracował w PGR Bodzechów jako ślusarz i monter. Kupił ciężarówkę, która była jego źródłem utrzymania; dodatkowo prowadził warsztat ślusarski. W okresie 19 marca-6 lipca 1949 r. był tajnym współpracownikiem PUBP w Ostrowcu Świętokrzyskim (nosił wówczas pseudonim „Kot”). Skreślony z listy TW za brak współpracy. Brał udział w zabójstwie Żydów w Goździelinie. 30 czerwca 1949 r. został tymczasowo aresztowany, a następnie zwolniony. 6 kwietnia 1959 r. został skazany przez Sąd Wojewódzki w Kielcach Ośrodek Zamiejscowy w Radomiu na łączną karę 10 lat więzienia i utratę praw na okres 5 lat. Sąd Najwyższy w dniu 12 kwietnia 1961 r., na mocy art. 8 § 1 ustawy o amnestii z 27 kwietnia 1956 r. postanowił umorzyć postępowanie przeciwko Tworkowi ${ }^{111}$.

Karol T. Wickenhagen (1901-1952), rotmistrz rezerwy kawalerii, od 1942 r. z polecenia KG AK prowadził w swoim majątku w Sobótce konspiracyjną szkołę podchorążych - 1. Pułk Szwoleżerów AK. W tym czasie przyjmował także wielu wpływowych Niemców. W lipcu 1943 r. pośredniczył w nawiązaniu kontaktów pomiędzy dowódcą oddziału NSZ wach. Tomaszem Wójcikiem „Tarzanem” (oficjalnie zatrudnionym jako karbowy), a por. Leonem Torlińskim „Kretem” z AK. W drugiej połowie 1944 r. w Sobótce odbyła się wspólna konferencja władz niemieckich z oficerami Inspektoratu AK Sandomierz oraz mjr. Leonardem Zub-Zdanowiczem z NSZ. Podczas konferencji Niemcy zaproponowali Polakom zawieszenie broni i skierowanie jej przeciwko komunistom. Propozycje te nie zostały przyjęte ${ }^{112}$.

Henryk Wierzbiński, „Topór”, „Toporek” (1918-?), urodził się w Jędrzejowicach, pow. Opatów, urzędnik, z zawodu spawacz, ukończył 2 klasy gimnazjum. Do ZWZ-AK został zwerbowany zimą 1941 r. przez Jana Śledzia „Jelenia”. Przysięgę odebrał od niego Roman Rożyński „Róg”. Na początku należał do placówki na terenie Ostrowca, werbował nowych ludzi, potem w placówce Częstocice, której

${ }^{111}$ AIPN Ki, 005/358, Ministerstwo Spraw Wewnętrznych, Biuro „C”, k. 5.

112 Więcej na ten temat zob. Marek Jan Chodakiewicz, Narodowe Sity Zbrojne - „Ząb” przeciw dwu wrogom, wyd. 2 uzup. i poszerz., Warszawa: Fronda, 1999, s. 147. 
komendantem był Tadeusz Mitelsztet „Turek”. W styczniu 1944 r. został zdekonspirowany i musiał się ukrywać, objął stanowisko instruktora szkoleniowego w Mikrowicach - przygotowywał ludzi do oddziału zbrojnego, tj. do pójścia do lasu. Przeszkolił sześciu ludzi, wszyscy wstapili do oddziału leśnego pod dowództwem „Jelenia” (Śledzia). 6 czerwca 1944 r. został przyjęty do oddziału „Zawiszy” i objął funkcję instruktora szkoleniowego w stopniu kaprala. Do 21 sierpnia 1944 r. był dowódcą 5. drużyny. Później zachorował i zwolnił się, przebywał na „melinie” u sołtysa gromady Rusinów [tak w aktach, nie ma takiej wsi w tych okolicach, być może chodzi Ruszków - J.M., A.S.], później u matki w Jędrzejowicach - aż do wyzwolenia. Jako dowódca 5. drużyny brał udział w koncentracji w pierwszych dniach sierpnia obok wsi Dębno i Jeziorko, gm. Nowa Słupia, skąd wyruszono w kierunku Warszawy. Po wojnie mieszkał w Koszalinie; nim tam wyjechał, był krótko funkcjonariuszem MO (instruktorem szkoły milicyjnej w Ostrowcu). W latach 1945-1948 należał do PPS. 25 lutego 1950 r. został skazany przez Sąd Apelacyjny w Kielcach na 15 lat więzienia i utratę praw na lat 10. Sąd Najwyższy w Warszawie 19 stycznia 1957 zmniejszył karę do 8 lat więzienia, a Sąd Wojewódzki w Kielcach orzekł 26 marca 1957 r. jego warunkowe, przedterminowe zwolnienie.

Władysław Zwiejski, „Jaruga” (1908-1998), urodził się we wsi Ruszków, pow. Opatów, w rodzinie chłopskiej. Po ukończeniu w roku 1928 gimnazjum w Ostrowcu Świętokrzyskim odbył służbę wojskową w Szkole Podchorążych Rezerwy Piechoty w Gródku Jagiellońskim (1928-1929), a następnie studiował na Wydziale Prawa Uniwersytetu Warszawskiego. W okresie 1934-1937 pracował w Urzędzie Skarbowym w Krzemieńcu, a w latach 1937-1939 był referentem prawnym w Liceum Krzemienieckim. W czasie wojny obronnej 1939 r. był dowódcą plutonu w stopniu porucznika. Po klęsce wrześniowej powrócił w strony rodzinne i włączył się w działalność konspiracyjnego ruchu ludowego; był członkiem Stronnictwa Ludowego „Roch” i komendantem Obwodu „6” (Opatów) Batalionów Chłopskich. Po wyzwoleniu, w latach 1945-1949, działał w PSL, a następnie w ZSL. Szykanowany przez władzę ludową, opuścił strony rodzinne i zamieszkał w Pasłęku, gdzie podjął pracę w sądownictwie, a następnie pracował jako radca prawny. Autor książki Walczyli w Chtopskich Batalionach (Warszawa 1964), w której opisał powstanie i działalność BCh w powiecie opatowskim.

\section{Słowa kluczowe}

Żydzi, Armia Krajowa, Kielecczyzna, powiat opatowski, oddział „Barwy Białe”, Kedyw Okręgu Radomsko-Kieleckiego AK, Goździelin, Lisów, Siekierno, Kazimierz Olchowik, „Zawisza”, 2. Dywizja Piechoty Legionów AK „Pogoń”, dekret sierpniowy

\section{Abstract}

The soldiers of "Barwy Białe" Home Army partisan detachment created at the end of 1943 in the Opatów district participated in at least a few murders of Jews - the mur- 
ders in Goździelin, Lisów and Siekierzyn forests are documented. The last crime, committed on 16 or 17 August 1944 when the detachment (at that time a part of the 2nd Infantry Division) was marching to aid warring Warsaw (as part of Operation Tempest). While quartered in Siekierno, the detachment's commanding officer Kazimierz Olchowik "Zawisza" issued an order to execute a big group of Jews (30-58 people) living in the nearby forests after their escape from the labor camp in Skarżysko-Kamienna. After World War II most participants of the murders were tried and punished. No punishment, however, was administered to the detachment's commanding officer Kazimierz Olchowik and to the sergeant by the pseudonym "Bolrok" - the two chiefly responsible for the murder in the Siekierzyn forests.

\section{Key words}

Jews, Home Army, Kielce Region, Opatów district, "Barwy Białe” detachment, Radom-Kielce Home Army Kedyw, Goździelin, Lisów, Siekierno, Kazimierz Olchowik, "Zawisza," 2nd "Pogoń" Division of the Home Army Legions, August decree 